\title{
Does fiscal decentralization mitigate the adverse effects of corruption on public deficits?
}

\author{
Daniel Oto-Peralías, Diego Romero-Ávila and Carlos Usabiaga \\ Pablo de Olavide University, Spain
}

\begin{abstract}
The current economic crisis has led several rich countries to experience severe fiscal deficits. Among other factors responsible for the situation, corruption is considered harmful to public finances and appears closely related to fiscal deficits. This paper opens a new avenue in addressing the effects of corruption on public deficits through fiscal decentralization. Focusing on a sample of 31 OECD countries over the period 1986-2010, we find that fiscal decentralization contributes to mitigating the perverse effects of corruption in public deficits. In addition, our findings indicate heterogeneity in the effect of fiscal decentralization, since it appears related to lower deficits in countries with higher levels of corruption, but not in less corrupt countries. Therefore, the results suggest that bringing the government closer to the people in relatively corrupt countries may lead to a more responsible fiscal management.
\end{abstract}

Keywords Corruption, Public Deficit, Fiscal Decentralization, OECD

JEL Classification D73, H62, H71, H72

Acknowledgements: The authors acknowledge financial support from the Spanish Ministry of Science and Technology through grant ECO2009-13357, the Spanish Ministry of Economics and Competitiveness through grant ECO2012-35430 and the Andalusian Council of Innovation and Science under Excellence Project SEJ-4546.

Daniel Oto-Peralías, Universidad Pablo de Olavide, Departamento de Economía, Métodos Cuantitativos e Historia Económica, Carretera de Utrera, Km. 1, Sevilla, Spain. E-mail: dotoper@upo.es.

Diego Romero-Ávila, Pablo de Olavide University, Departamento de Economía, Métodos Cuantitativos e Historia Económica, Carretera de Utrera, Km. 1, Sevilla, Spain. E-mail: dromtor@upo.es.

Carlos Usabiaga. Pablo de Olavide University, Departamento de Economía, Métodos Cuantitativos e Historia Económica, Carretera de Utrera, Km. 1, Sevilla, Spain. E-mail: cusaiba@upo.es. 


\section{Introduction}

Nowadays, achieving sustainable public finances is a first order concern in rich countries. The current economic crisis has led several countries to experience severe fiscal deficits, going so far as to make it impossible for some of them to obtain funding without international bailouts. Among other factors responsible for this situation, corruption is considered an important institutional feature which is harmful to public finances and appears closely related to fiscal deficits. In the view of the World Bank (2012a), corruption "reduces the effectiveness of public administration and distorts public expenditure decisions, [...] erodes the rule of law and harms the reputation of and trust in the state". More specifically, corruption leads to adverse budgetary consequences by decreasing state revenue and promoting wasteful spending. Corruption practices are associated with tax evasion, unofficial economy, illegal customs administration, irregular procurements, thefts and bribes or "white elephant" investment projects (World Bank, 2012b).

As pointed out by Kaufmann (2010), it is interesting to note that, contrary to common belief, there exist large differences regarding the presence of corruption among industrialized countries. To get an overview of these differences, focusing on our sample of OECD countries, the Global Corruption Barometer 2006 of Transparency International reports bribe payments values ranging between 1 percent (Finland, Sweden and Switzerland) and 17 percent (Czech Republic and Greece). ${ }^{1}$ With respect to the consequences on public finances, Kaufmann (2010) observes a strong relationship between corruption and fiscal deficits in rich countries. An illustration of this relationship is presented in Figure $1 .^{2}$

\section{[Insert Figure 1 about here]}

Bearing this in mind, this paper opens a new avenue in accounting for the fact that the adverse effects of corruption on public deficits may be mitigated through fiscal decentralization. The intuition behind this proposition is that when the government does not work well, by misusing public office for private gain, a close citizen control of politicians is particularly necessary. The monitoring of political activity -in general- and fiscal management -in particular- can be facilitated by bringing the government closer to the people, which leads to higher information about local affairs and a higher degree of democracy and accountability. The same logic suggests that if corruption is absent, to decentralize

\footnotetext{
${ }^{1}$ Literately, the question included in the Barometer is as follows: "In the past 12 months, have you or anyone living in your household paid a bribe in any form?” (Transparency International, several years).

${ }^{2}$ See below for the explanation of the variables employed.
} 
may be less necessary in this regard. In addition, it may be argued that in a context of rampant corruption, it is preferable to have several levels of government rather than an omnipotent and opaque central government that appears to be very far from citizen control.

When one observes decentralization across OECD countries, the differences are striking. Considering the amount of subnational tax revenue as a percentage of total general government tax revenue, we find great variability within our sample over the period 1986-2010. The range runs from countries like Greece, with a value lower than one percent, to countries like Canada, with a value near 50 percent.

Casual observation supports our argument. Greece, a country relatively corrupt, presents both the lowest level of fiscal decentralization and the highest deficit in the analyzed period. This stands in stark contrast to the experience of countries like Poland, which reports higher decentralization and lower deficits, despite having at least similar levels of corruption. The comparison of the two countries suggests a connection between more fiscal decentralization and fewer deficits. In contrast, among less corrupt countries, decentralization appears unrelated to public deficit. Thus, the Netherlands and Canada present similar levels of corruption and similar records of deficits, the former being much less decentralized than the latter. Table 1 summarizes the data of the four countries mentioned. ${ }^{3}$

\section{[Insert Table 1 about here]}

These observations lead us to systematically study the relationship between corruption, fiscal decentralization and public deficit. Using a sample of 31 OECD countries, we show that the relationship between corruption and public deficit is nonlinear and varies with the degree of fiscal decentralization. Thus, we find that the effect of corruption on increasing fiscal deficit goes down as the level of decentralization rises. In addition, we observe that fiscal decentralization is related to lower deficit only in countries with higher levels of corruption, but not in less corrupt countries.

Therefore, the central message this paper conveys is that fiscal decentralization mitigates the adverse effects of corruption on public deficit. We adopt several econometric approaches to provide empirical evidence supporting our main argument. First, we estimate cross-section and panel regressions for the

\footnotetext{
${ }^{3}$ In general, the literature on fiscal decentralization predicts ambiguous effects on public deficits. On the one hand, to decentralize means bringing the government closer to the people and encourages competition among subnational jurisdictions. This leads to better information about local affairs, higher accountability, more efficient provision of public services, responsible fiscal management and moderate size of government (Oates, 1999; Brennan and Buchanan, 1980). But decentralization is considered as a "double-edged sword". Several problems have been identified, such as the risk of duplicating functions and wasting resources, coordination failures, a "race to the bottom" due to interjurisdictional competition -with the subsequent erosion of government revenue sources-, "soft budget constraints” and the lower expertise of local governments (Prud'homme, 1995; Weingast, 2009).
} 
period 1986-2010 by using an interaction model where public deficit is explained through corruption, fiscal decentralization and an interaction term of both variables. Second, the sample is divided into three groups according to the level of corruption so that we can examine whether decentralization is related to lower deficit in each of them. For the first purpose, we use ordinary least squares (OLS) and the system GMM estimator and, for the second, fixed effects models. The results hold for both revenue and expenditure indicators of decentralization and they are fairly robust to different specifications.

The remainder of the paper is organized as follows. Section 2 reviews the relevant literature on corruption, fiscal federalism and public deficit, as well as outlines possible hypotheses about the impact of the interaction between corruption and decentralization on public deficits. Section 3 presents the methodological approach and takes a first look at the data. Section 4 presents the results from the main regression analysis. Section 5 provides several robustness checks as well as a complementary analysis that divides the sample into three groups according to the average corruption level and focuses on within-country variation. Section 6 puts forward some policy implications and concludes.

\section{Theoretical and empirical background}

Our research is placed between two well-differentiated branches of the institutional literature, namely, the consequences of corruption -on one side- and decentralization -on the other- in the economy and governance. We first review both branches separately and we then adopt an integrative view in order to interpret the interaction between corruption and decentralization.

For more than a decade the consequences of corruption have been studied profusely by economists and political scientists. A seminal contribution on the effects of corruption on the economy is Mauro (1995, 1997), who finds that corruption reduces investment and hence economic growth. Since then, many authors have found evidence on the negative impact of corruption on different areas of economic activity, such as foreign direct investment, countries' infrastructures, investment, public spending effectiveness or sustainable development (see, among others, Wei, 1997a and 1997b; Tanzi and Davoodi, 1998; Aidt et al., 2008; Rajkumar and Swaroop, 2008; Aidt, 2009). Regarding public finances, the World Bank (2012b) stresses that corruption is harmful to state coffers by decreasing state revenue and promoting wasteful spending. Corruption encourages tax evasion, tax regressivity and the unofficial economy. It is also associated with corrupt procurement with cost overrun, cases of theft, "white elephant" investment projects and purchasing of political support. High level of corruption reduces tax revenue particularly from social security tax and -to a lower extent- sales tax. 
Extrabudgetary accounts (with lower political and administrative controls) and goods and services provided below market prices are also fertile grounds for corruption to flourish (Tanzi, 1999). In a study of US states, Depken and Lafountain (2006) find that corruption is related to lower bond rating, which implies the payment of a premium for state bonds.

Focusing on industrialized countries, Kaufmann (2010) lists a number of channels whereby corruption can affect public finance, which can be divided into direct and indirect channels. The former are a) the erosion of tax revenue through evasion and ineffective tax collection institutions and b) the increase of public expenditures associated with inflated bureaucracies, expensive public investments and inefficient composition of public spending. The indirect channels are a) the rising cost of debt service and the lack of transparency of the financial sector, b) corrupt data of financial and national statistics, which leads to uncertainty and mistrust in the financial markets, c) the shadow economy, which leads to an increase in official tax rates to compensate for the overall fall in tax revenues, and d) lower productivity, competitiveness and growth (by raising -for instance- the cost of doing business), which are the ultimate sources of government revenue. Kaufmann (2010) finds that corruption is strongly related to fiscal deficits in rich countries. One standard deviation improvement in the corruption indicator leads to a 3.5 percentage point reduction in fiscal deficits. Besides Kaufmann's work, very little has been done to investigate the relationship between corruption and public finance in rich countries. In this respect, we provide further evidence showing that corruption increases fiscal deficits in rich countries.

Another extensively studied topic over the last two decades is the impact of decentralization on economic activity and governance. Nowadays, we are witnessing a global trend of devolution process (see, for instance, Rodríguez-Pose and Gill, 2003). Many states have conducted and are still involved in decentralization processes in order to achieve economic, social and democratic goals. Although initially decentralization initiatives were seen with optimism, scholars soon began to doubt about the merit of such endeavours. The attitude change was due, at least partially, to the dismal performance of subnational levels in some countries (Oates, 2008). Argentina and Brazil suffered severe fiscal crisis largely motivated by irresponsible behavior of subnational governments (Dillinger and Webb, 1999). ${ }^{4}$

\footnotetext{
${ }^{4}$ We focus particularly on fiscal decentralization since our interest lies in the distribution of fiscal competences among different levels of government. Nevertheless, it is important to keep in mind that the different facets of decentralization are related among them. For example, vertical fiscal imbalances, -i.e., dependence on financial resources from higher levels of government-, endanger the political autonomy of subnational governments (Weingast, 2009).
} 
The literature on fiscal federalism provides arguments both in favor and against decentralization. First of all, to decentralize means bringing the government closer to the people. This has many implications, namely, a higher level of knowledge and information about local affairs, leading to a more efficient and better provision of public services (Oates, 1999), and higher degree of democracy and accountability, allowing the control of corrupt behavior. Secondly, it has been argued that the existence of a number of sub-national jurisdictions encourages competition among them in order to satisfy people's preferences. The widely known “Tiebout model” supports the fact that mobile households select those jurisdictions that better match with their preferences about public goods and taxes by voting "with their feet” (Tiebout, 1956). Officials and politicians will be compelled to a responsible management of fiscal resources and to provide valuable public services (Oates, 1999). Also, in a related fashion, a plurality of subnational governments is considered to favor the functioning of economic markets ("market-preserving federalism” -Weingast, 1995) and limit the size of the “Leviathan” (Brennan and Buchanan, 1980). For all these reasons, second generation fiscal federalism models stress the important role played by own revenue generation -tax autonomy- by subnational governments (Careaga and Weingast, 2003; Rodden, 2003). ${ }^{5}$

Regarding the arguments against fiscal decentralization, interjurisdictional competition can generate a "race to the bottom" because it creates incentives for subnational governments to reduce tax rates and regulation standards in order to attract business to the jurisdiction. This erodes their revenue sources, thus causing serious fiscal imbalances. On the other hand, "soft budget constraints" and an excessive dependence on intergovernmental transfers are related to irresponsible fiscal management (Weingast, 2009). ${ }^{6}$ Additionally, as mentioned by Treisman (2002), it has been argued that multi-tier governments are more likely to duplicate functions and waste resources. Likewise, when economies of scale exist, subnational governments are less efficient in providing public goods and services if they lack the adequate size (Rodríguez-Pose and Ezcurra, 2011). Other negative aspects of decentralization include coordination problems due to the presence of a high number of veto players and the lower capacity and skills of local governments (Prud'homme, 1995).

\footnotetext{
${ }^{5}$ In favor of federalism, it has been also said that it allows for a higher degree of institutional and policy experimentation. A federal system offers the possibility of public policy innovation by a decentralized process of "learning-by-doing" in different circumscriptions (Oates, 1999). In the US there are several examples of federal policies that were designed and used formerly in subnational levels -for instance, the unemployment insurance, the taxation of gasoline and the regulation of emissions standards for motor vehicles (Oates, 2008).

${ }^{6}$ It is emphasized the importance of revenue generation by state and local governments. In a review of the second generation models of fiscal federalism, Weingast (2009) asserts that "subnational governments that raise a substantial portion of their own revenue tend to be more accountable to citizens, to provide market-enhancing public goods, and to be less corrupt” (p. 283).
} 
Several empirical works have addressed the question of the relationship between decentralization and public deficits. For a sample of 30 developed and developing countries during the period 1970-1995, De Mello (2000) finds subnational tax autonomy to be associated with larger deficits, which he relates to coordination failures in intergovernmental fiscal relations. Focusing on a sample of 17 federations, Rodden and Wibbels (2002) provide evidence that fiscal decentralization is associated with smaller overall deficits, particularly when subnational governments have wide autonomy over taxation. In contrast, public deficits increase as subnational governments rely more on intergovernmental transfers. Shah (2006) comes to the conclusion that decentralized fiscal systems permit (or facilitate) to a higher extent improved macroeconomic governance compared to centralized systems. In general, he finds fiscal decentralization to be related to better fiscal performance. ${ }^{7}$ In addition, Baskaran (2010) explores the relationship between fiscal decentralization and public debt within a panel of 17 OECD countries from 1975 to 2001. His findings indicate that expenditure decentralization reduces public debt, whereas tax decentralization and vertical fiscal imbalances are not significantly related to it. Baskaran (2012) analyzes the influence of sub-national tax autonomy in public deficits with a sample of 23 OECD countries over the last quarter a century. Sub-national tax autonomy shows a U-shaped effect, so the 'average OECD country' could reduce the fiscal deficit by decreasing sub-national tax autonomy.

We also find a paper by Neyapti (2010) that is related to our analysis. Her study shows that both expenditure and revenue decentralization reduce budget deficits for a sample of developing and developed countries over the period 1980-98. In addition, she uses an interaction model providing some preliminary evidence that the effect of fiscal decentralization on reducing budget deficits increases with population size and that the effect of expenditure decentralization is reduced when governance improves. Our analysis differs from Neyapti’s in several important respects. First, unlike her sample of 16 countries that only includes nine OECD countries (while the rest are developing countries as diverse as Bolivia, Brazil, Colombia, Iran, Malaysia, Mexico and South Africa), our dataset is based on a more homogeneous sample comprising 31 OECD countries. The advantage of doing so is that most OECD countries are characterized by having democratic regimes and relatively educated populations, and the risk of omitted variables bias and measurement errors is attenuated. ${ }^{8}$

\footnotetext{
${ }^{7}$ In Shah's view, that result is expected since decentralized fiscal systems imply clarity in the role of decision-making units, transparency in the rules and a careful institutional design thought to achieve fair play and restrict rent seeking behavior.

${ }^{8}$ So, taking as reference the year 2000, all of the 31 OECD countries of our sample are "Free" according to the Freedom House's classification of political status. Regarding the level of education, which is important in order to make an effective control of government activity feasible, the secondary school enrolment is above $85 \%$ in all
} 
This allows us to better identify the effects of fiscal decentralization and its interaction with corruption on fiscal deficits, thereby enabling us to provide some policy implications and advice better suited for industrialized countries. Second, by taking the period covering the years between 1986 and 2010 we are able to extend Neyapti's time span by 12 years, which entails the most recent period in which tax and expenditure decentralization has intensified (Stegarescu, 2005).

Third, while this author treats fiscal decentralization (as well as the other regressors) as exogenous, we allow all explanatory variables to be endogenous with respect to fiscal deficits. ${ }^{9}$ We deal with this issue by using the system GMM estimator of Arellano and Bover (2005) with both annual and 5-year average data (which should also help to correct for real business cycle effects) versus the pooled OLS estimator of Neyapti that fails to accommodate the presence of endogeneity in the regressors. Fourth, whereas she interacts -in only one model- fiscal decentralization with a broad measure of governance which includes a wide variety of factors such as control of corruption, rule of law, political instability, government efficiency, voice accountability and regulatory quality, our paper focuses the whole empirical analysis on corruption and its interaction with fiscal decentralization. We do so because corruption is the aspect of governance that is generally emphasized in both the theoretical and empirical literature on fiscal decentralization and fiscal outcomes. ${ }^{10}$ Fifth, we conduct extensive robustness checks where we introduce many additional control variables, test the presence of outliers and even use alternative empirical approaches. Not surprisingly, our results differ substantially from Neyapti for the revenue decentralization measure. Whereas we find robust evidence that tax decentralization leads to lower deficits only in countries with high corruption, her evidence points to the fact that "governance [does] not seem to influence the effectiveness of revenue decentralization" (Neyapti, 2010, p. 161).

After reviewing the literature on the consequences of corruption and decentralization in public finance, we raise the question of what the effect of their interaction is. Is the effect of corruption independent of the level of decentralization? Does fiscal decentralization mitigate or aggravate the adverse effects of corruption on public deficit? What result is to be expected from that interaction? An a priori answer is necessarily ambiguous. On the one hand, decentralization may exacerbate public finance

countries (World Bank, 2011). In addition, common forces such as economic integration measured by trade and financial openness are found to increase fiscal decentralization in the OECD (Stegarescu, 2009).

${ }^{9}$ It is not difficult to show how, for instance, GDP growth affects negatively fiscal deficits and how the latter in turn reduces economic growth by inducing spending cuts and tax increases.

${ }^{10}$ In addition, while the governance indicator is only available since 1996, our corruption measure from the International Country Risk Guide is available for the whole period under scrutiny (1986-2010). 
mismanagement in a corrupt context. Local government may be captured by local elites and corrupt politicians without proper citizen control. Political patronage is another pathology of corrupt governments that may be aggravated at local levels, with negative consequences for spending and revenue decisions. More actors involved in fiscal management implies that the pie must be divided into more pieces, which may lead to more private appropriation of public funds. In addition, coordination problems and fiscal imbalances may be exacerbated when corruption exists, since budget monitoring and public finance transparency tend to be lower. Hence, a plausible hypothesis is that when the government is corrupt, many government levels will worsen rather than improve the situation. ${ }^{11}$

However, a more optimistic view is possible. A corrupt government is characterized by opaqueness and lack of accountability, whose decisions are taken without citizen control. In this case, central government is a Leviathan that extracts rents from population and uses them for private gain of politicians and officials. Decentralizing fiscal powers gives citizens the opportunity to increase the control of public money management. Arguably, if the central government is corrupt, fiscal decentralization is more necessary as an institutional mechanism that helps to prevent the irresponsible management of public funds. A government closer to the people is a government subject to more oversight and more effective accountability. This is because citizens are more interested and informed about local affairs, thereby being better able to punish irresponsible political behavior, for instance, through subnational and local elections. By contrast, when government is transparent and open, and politicians and public employees honest and upright, then the central government may function well without need for decentralization. Although it may be argued that decentralization -as well as democracy- is always desirable, in a context of low corruption it is less necessary because the government performs properly and does not misuse public funds. In this case, citizen control is not so

\footnotetext{
${ }^{11}$ A related question is whether decentralization increases corruption. Fisman and Gatti (2002) obtain a strong and significant effect of government expenditure decentralization on reducing corruption. Along similar lines, Ivanyna and Shah (2010), focusing on the local government level for a large sample of countries, find that local fiscal decentralization has a significant negative effect on the incidence of corruption. This would accord with the prediction of theoretical models such as the ones by Shleifer and Vishny (1993) and Kotsogiannis and Schwager (2006) for which greater decentralization limits corruption by raising competition among subnational governments. Arikan (2004) provides less clear-cut evidence of a reduction in corruption due to higher decentralization, since only about half of the decentralization coefficients appear statistically significant. In contrast, using measures of corruption experiences and a large sample of countries around the world, Fan et al. (2009) point to the danger of uncoordinated rent-seeking when government structures increase in complexity. In this sense, a larger number of tiers and a larger local staff -"with pockets to fill" - increase the chances of "overgrazing" in the rents of public office. In conclusion, these works show that there is no consensus about the effect of decentralization on corruption.
} 
essential, and one can expect the positive effect of fiscal decentralization on reducing budget deficits to be lower in a transparent country. ${ }^{12}$

Since there is theoretical ambiguity about the effect of the interaction between corruption and decentralization on fiscal deficits, an empirical inquiry is warranted. This is what we do in the rest of the paper.

\section{Methodology and data}

We select a sample of 31 OECD countries, which includes all current members except Chile, Mexico and Turkey, due to missing data. The use of a sample of rich countries has several advantages, such as greater data availability and lower heterogeneity across countries. This last aspect implies that we are comparing relatively homogeneous countries, with well-developed economies and democratic regimes. When analyzing the mechanism by which decentralization affects governance, it is important to keep in mind the features characterizing the countries included in our sample (high average levels of education and income, political freedom, levels of corruption relatively lower than non-OECD countries, and so on). Also, this greater sample homogeneity leads to more meaningful results and reduces the risk of omitted variable bias. The period under scrutiny spans from 1986 to 2010, since available data on corruption begin in the mid-eighties. The source of institutional data is the International Country Risk Guide (ICRG) produced by the Political Risk Services Group (PRS Group, 2012).

Firstly, we estimate an interaction model where public deficit is explained by corruption, fiscal decentralization, the interaction between these two and several control variables. We calculate crosssection regressions with OLS by averaging the variables over the whole period. This can be thought of as the analysis of the long-term relationship between the variables under study. We also estimate panel regressions in order to exploit the time variation of the data, using both annual and five-year averaged data. In this case, we use pooled OLS and the system GMM estimator. Secondly, we divide the sample into three groups based on the average level of corruption. This exercise can be proven meaningful since corruption -as many other institutional variables- is remarkably persistent over time. ${ }^{13}$ With

\footnotetext{
${ }^{12}$ Likewise, one can argue that other disciplining mechanisms working in decentralized governments such as jurisdictional competition play a more important role when corruption is higher. We will insist on this point in Section 5.3 .

${ }^{13}$ In order to check the persistence of corruption over time, we can divide the sample into two periods (1984-1997 and 1998-2010) and calculate the average value of corruption for each country in both periods (using ICRG data). The correlation between the two periods is 0.87 .
} 
countries classified into three groups, we ask whether there are significant cross-country differences regarding the effect of decentralization on public deficits. For that purpose, we use a fixed effects model, which controls for all time-invariant characteristics and exploits within country variations. In this way, corruption is held constant and instead we focus on the variation in fiscal decentralization.

Regarding the measure of corruption, we concentrate on public corruption and adopt a widely extended definition of corruption as the misuse of public office for private gain (see, among others, Tanzi, 1999). Our main measure is a perception-based indicator from the ICRG (hereafter, ICRG corruption). This indicator assesses, on a scale of 0 to 6 , the presence of corruption within the political system. ${ }^{14}$ It measures different facets of corruption, such as financial corruption (requirements of special payments and bribes), political patronage, "wire-pulling”, secret party funding, and ties between politics and business (PRS Group, 2012). We prefer this variable over other alternatives due to the greater time span availability. Unlike our corruption measure, the indicators Control of Corruption from the World Bank Governance Indicators (Kaufmann et al., 2010) and Corruption Perceptions Index from Transparency International are only available since 1996 and 1995, respectively. Experience-based indicators from comparable international surveys are much more limited both in the time dimension and in the sample of countries covered. Correlations among perception-based indicators are high, indicating that they are measuring more or less the same thing; while correlations among these indicators and experience-based indicators are lower. ${ }^{15}$

With respect to fiscal decentralization, our preferred indicator is subnational (state/regional and local) tax revenue as a percentage of total general government tax revenue (hereafter, subnational tax revenue), which is a measure of revenue decentralization and comes from the OECD Fiscal Decentralisation Database (OECD, 2012a). This indicator is interesting because it focuses on tax revenue generated at subnational levels, rather than other sources of revenue such as intergovernmental transfers, which depend on the central government. It has been argued that decentralization based on own revenue leads to more accountability, less corruption, more marketenhancing public goods and more political autonomy (Weingast, 2009). Nevertheless, our indicator is imperfect, since it does not reflect the degree of autonomy of subnational governments in deciding the

\footnotetext{
${ }^{14}$ Country-specific annual scores are computed as the average over the 12 months for each year (PRS Group, 2012). This makes the variable take values over the continuum between 0 and 6 . We rescale the variable so that higher scores imply more corruption.

${ }^{15}$ The correlation of ICRG corruption with Control of Corruption is $0.82(N=337)$ and with Corruption Perception Index $0.76(N=478)$. The correlation with the variable bribe payments (percentage of population paying bribes in the last year), an experience-based indicator from the Global Corruption Barometer, is $0.53(N=134)$.
} 
tax characteristics (tax base, rates, reliefs, etc.). Stegarescu (2005) -following the classification proposed by the OECD (1999)- provides a measure of subnational tax autonomy (that spreads until 2001) by selecting only autonomous own tax revenue of subnational governments, that is, those for which sub-central government determines the tax rate and/or the tax base. For robustness purposes, we update Stegarescu's best measure of tax decentralization (i.e. TDl) by using the information about tax autonomy of state and local governments provided by the Fiscal Decentralization Database of the OECD for the years 2002, 2005 and 2008 (OECD, 2012a). Remarkably, the subnational tax revenue and TD1 indicators are strongly correlated. ${ }^{16}$ In addition, in order to test whether the effect of expenditure decentralization is different from that of tax decentralization, we also estimate regressions using "subnational government expenditure as a percentage of total general government expenditure" -hereafter, subnational govern. expend. (OECD, 2012a).

Our dependent variable is general government deficit over GDP obtained from the Economic Outlook of the OECD (2012b). We do not use subnational or central deficits because what matters is the behavior of the whole political system. Moreover, irresponsible fiscal policies of subnational governments may not be associated with higher subnational deficits if the central government issues debt and increases transfers to subnational units. As Treisman (2002) notes, it makes no sense to advocate decentralization on the basis of better local government performance when it is offset by a deterioration of central government accounts.

In all the estimations we always include a basic set of control variables. Total government revenue over GDP is included to control for countries' capacity to collect taxes and for government size. The expected sign is ambiguous since greater revenue capacity allows covering expenditures, but large governments are related to economic inefficiencies and distortions. Real per capita GDP growth and unemployment rate control for business cycle effects. We expect economic growth to reduce and unemployment rate to increase fiscal deficits. The logarithm of per capita GDP is also included to control for the level of economic development. The effect of this variable is uncertain since wealthier countries are associated with a higher demand for goods and services provided by the government (the Wagner's law) but also these countries can afford more effective tax administration and are less likely to be affected by tax evasion. Finally, population is introduced due to the important variability in the

\footnotetext{
${ }^{16}$ The correlation between subnational tax revenue and Stegarescu's indicator of tax decentralization is $0.874(N=$ 357). After updating the indicator, the correlation is almost identical $(0.875, N=403)$.
} 
size of the countries in the sample and because it probably affects public finances (scale effects, for instance) and promotes decentralization. ${ }^{17}$

Before starting the regression analysis, Table 2 provides a first look at the relationship between corruption, fiscal decentralization and public deficit. Countries are classified into three groups according to their level of corruption. ${ }^{18}$ Within each group, countries are separated on the basis of their degree of tax decentralization. The entries represent the average values over the period 1986-2010. The aggregate data for each group (rows with bold letters) reveal a positive association between corruption and public deficit, which fits with the relationship depicted in Figure 1 (see Introduction). We see that more corrupt countries exhibit higher deficits, being the difference relative to less corrupt countries of nearly 4 percentage points (3.98 vs. 0.08). In each corruption group, one observes that corruption affects deficits differently depending on tax decentralization. Considering the 'high corruption group', less decentralized countries suffer higher deficits than more decentralized ones, with a difference of 3.5 percentage points. ${ }^{19}$ In the 'intermediate corruption group', less decentralized countries also suffer higher deficits, but the difference with respect to more decentralized ones is lower (0.68 percentage points). Finally, focusing on the 'low corruption group', we observe a very different pattern. In this case, less decentralized countries experience lower deficits than those more decentralized, the difference being 2.3 percentage points. Therefore, this preliminary evidence indicates heterogeneity in the relationship between decentralization and public deficit, depending on the level of corruption. Fiscal decentralization is related to lower public deficits in a context of relatively high corruption, but not in a context of low corruption.

\section{[Insert Table 2 about here]}

\section{Regression analysis}

\subsection{Cross-section regressions analysis}

We estimate in this section a basic interaction model of the following form:

\footnotetext{
${ }^{17}$ The definitions and sources of the variables are presented in Appendix I. The descriptive statistics are provided in an unpublished appendix available from the authors upon request.

${ }^{18}$ We calculate the average value of our main indicator of corruption, ICRG corruption, by using all available data (the period 1984-2010). Then, countries are divided by the $33^{\text {th }}$ and $66^{\text {th }}$ percentiles of this variable. More details are provided in subsection 5.2 .

${ }^{19}$ Note that this difference is not simply due to a higher level of corruption among less decentralized countries. In fact, the level of corruption is higher among more decentralized countries (2.67 vs. 2.20).
} 


$$
\text { deficit }_{i}=\alpha+\beta_{1} \cdot \text { corruption }_{i}+\beta_{2} \cdot \text { decentr }_{i}+\beta_{3} \cdot \text { corruption } \text { decentr }_{i}+\delta \cdot X_{i}+\varepsilon_{i}
$$

where deficit $_{i}$ is general government deficit, $\alpha$ is a constant term, corruption $_{i}$ is our main corruption indicator (ICRG corruption), decentr $r_{i}$ represents fiscal decentralization, corruption $\times$ decentr stands for the interaction term between the last two variables, $X_{i}$ is a vector of control variables and $\varepsilon_{i}$ is the error term. ${ }^{20}$ All the variables are included as the average over the period 1986-2010.

Table 3 reports results from cross-section regressions estimated with OLS. Column 1 shows the basic model without fiscal decentralization variables. Corruption is significantly related to higher fiscal deficits. An increase by one standard deviation in corruption (0.89) is associated with an increase of 1.15 percentage points in public deficit. The next column adds subnational tax revenue, which enters with a negative and significant coefficient. Now, corruption appears statistically insignificant. But since we suspect the existence of heterogeneity in the relationship between corruption and public deficit depending on the degree of fiscal decentralization, column 3 includes the interaction term between corruption and tax decentralization. In this model the interpretation of the coefficients is very different. The coefficient on corruption shows the effect on public deficit when subnational tax revenue is equal to zero, while the negative coefficient on the interaction term indicates that the effect of corruption on fiscal deficit decreases as tax decentralization increases. Therefore, we must conduct a conditional interpretation of the marginal effect of corruption for each value of tax decentralization (see Brambor et al., 2006). The marginal effect is given by:

$$
\frac{\text { ddeficit }}{\text { dcorruption }}=\beta_{1}+\beta_{3} \cdot \text { decentr }
$$

where $\beta_{1}$ is the coefficient on corruption and $\beta_{3}$ the coefficient on the interaction term. It is also necessary to properly calculate the standard error of the marginal effect, which is given by (see Aiken and West, 1991)::

$$
\hat{\sigma}_{\frac{\text { odeficit }}{\text { ocorruption }}}=\sqrt{\operatorname{var}\left(\hat{\beta}_{1}\right)+\text { decentr }^{2} \cdot \operatorname{var}\left(\hat{\beta}_{3}\right)+2 \cdot \text { decentr } \cdot \operatorname{cov}\left(\hat{\beta}_{1} \cdot \hat{\beta}_{3}\right)}
$$

At the bottom of Table 3, we calculate the marginal effects and standard errors of corruption for different values of tax decentralization (percentiles $10^{\text {th }}$ to $90^{\text {th }}$ ). The marginal effect of corruption on

\footnotetext{
${ }^{20}$ Note that the model includes all constitutive terms of the interaction. In order for coefficients to be meaningful, Brambor et al. (2006) show that interaction models must comprise all constitutive terms of the interaction.

${ }^{21}$ In an interaction model, for interpretation purposes, the relevant standard errors are those calculated in this way rather than the standard errors of the constitutive or interaction terms (Brambor et al., 2006).
} 
public deficit is positive and significant only when tax decentralization is low. For values equal or greater than the $50^{\text {th }}$ percentile, that is, subnational tax revenue equal to $10.5 \%$, the marginal effect is no longer significant and even the sign changes (see column 3). Regarding the control variables, economic growth and unemployment show the expected negative and positive signs, both variables being statistically significant. Total government revenue as a percentage of GDP presents a negative but insignificant coefficient, as it is the case also for per capita GDP. Population appears with a positive coefficient, sometimes statistically significant.

\section{[Insert Table 3 about here]}

It is interesting to note that we are controlling for government revenue, economic growth, and so on, which are some of the potential indirect channels through which corruption can affect public deficits (Kaufmann, 2010). For comparison purposes, column 4 excludes the set of control variables. As expected, the impact of corruption is now larger and tax decentralization contributes to a lower extent to reduce this effect. Thus, the threshold of tax decentralization beyond which corruption does not increase public deficit is now higher. Columns 5 to 7 are equivalent to columns 2 to 4 but with subnational govern. expend. as an alternative indicator of fiscal decentralization. The conclusions derived from this alternative indicator are $\operatorname{similar}^{22}$, even though Australia, Greece and Japan are omitted due to unavailable data on expenditure decentralization. Figure 2 depicts the marginal effect of corruption on public deficit depending on the degree of fiscal decentralization. The figure summarizes the main finding of the paper: corruption raises public deficit when fiscal decentralization is low, whereas no significant effect is found when the degree of decentralization increases.

\section{[Insert Figure 2 about here]}

Finally, it is possible to read the results from a different angle, namely, focusing on the marginal effect of fiscal decentralization depending on the level of corruption. This is what we do in Figure 3, which reports heterogeneity in the marginal effect of tax and expenditure decentralization, depending on the corruption level. Interestingly, when corruption is low the impact of fiscal decentralization is insignificant, but as corruption becomes more prevalent, decentralizing decreases fiscal deficits.

\section{[Insert Figure 3 about here]}

\footnotetext{
${ }^{22}$ To interpret the results, one must keep in mind the range of variation of fiscal decentralization indicators. While values for subnational tax revenue vary from 0.9 to 46.4, subnational govern. expend. ranges from 10.3 to 61.
} 


\subsection{Panel data analysis}

We now turn to panel estimation methods to further test the empirical regularity found. This is appropriate for several reasons. Panel estimations exploit the temporal variation in the data, thus improving efficiency. Also, some variables change significantly over time, so taking averages for extended periods is not highly recommended. Moreover, better estimators are available to control for endogeneity by using lags of the variables as instruments. We use both annual and averaged data over 5-year intervals for our computations, since it is unclear the exact time frame one should expect before corruption and decentralization changes influence public deficits.

Table 4 presents the results from the panel analysis using subnational tax revenue as the fiscal decentralization indicator. The first two columns show the coefficients obtained with pooled OLS, where we also include time-specific effects (year dummies) to account for common shocks affecting all countries in a given period. ${ }^{23}$ Column 1 indicates that corruption is strongly associated with public deficits, while the next column shows that the effect of corruption depends on the degree of tax decentralization. Compared to cross-section analysis (Table 3), in this case a higher level of decentralization is necessary for the effect of corruption to cease to be significant (subnational tax revenue around 20\%). The results remain unaltered in columns 5 and 6 that employ data averaged over 5-year intervals.

\section{[Insert Table 4 about here]}

However, pooled OLS only serves as a first approximation. Other methods are necessary to control for countries' permanent characteristics as well as for endogeneity problems. Fixed effects models with country-specific effects are not recommended in this case due to the fact that our main explanatory variable -corruption - is highly persistent over time and many of the regressors are thought to be endogenous. The difference GMM estimator (Arellano and Bond, 1991) addresses endogeneity problems by using previous realizations of the regressors to instrument for their current values in the first-differenced specification. However, Arellano and Bover (1995) and Blundell and Bond (1998) show that in the case of highly persistent regressors, lagged levels of the variables are weak instruments for the first-differenced regressors. This leads to a fall in precision as well as to biased coefficients. In order to overcome these shortcomings, these authors recommend the use of the system GMM estimator that utilizes instruments in levels and first-differences to improve in efficiency.

\footnotetext{
${ }^{23}$ Strictly speaking, this estimator is labelled as one-way fixed effect model with time dummies.
} 
Consequently, we will estimate the model using this estimator, which employs previous realizations of the regressors to instrument for their current values in the first-differenced specification and the lagged differences for the regression in levels. In order to avoid using an excessive number of instruments in a context with a relatively short cross-country dimension, we follow the suggestion of Roodman (2009) and limit the set of instruments to the minimum, i.e. to the first available: $x_{i t-2}$ for the specification in first-differences and $\Delta x_{i t-1}$ for the specification in levels. ${ }^{24}$ We use the one-step estimator since standard errors for the two-step estimator are biased downwards. We apply orthogonal deviations, which help to maximize the sample size in panels with gaps, like ours (Roodman, 2006). All our regressors are treated as endogenous variables (except time-period dummies).

The consistency of the system estimator depends on the validity of the instruments and the absence of serial correlation of second-order in the first-differenced error term. Therefore, we test these assumptions using the Hansen test for over-identifying restrictions and the test for second-order autocorrelation proposed by Arellano and Bond (1991). Failure to reject the null hypotheses of overall validity of the instruments and absence of second-order serial correlation in the first-differenced error for the respective tests would give support to the model.

Columns 3 and 7 confirm that corruption increases public deficit. The interaction models specified in columns 4 and 8 show that this effect is conditioned to the level of tax decentralization. They indicate that a one point increase in the corruption index leads to about 1.4 and 1.5 percentage points rises in public deficits when subnational tax revenue is lower than the $10^{\text {th }}$ percentile. However, as the degree of decentralization rises, the effect of corruption becomes smaller, being insignificant at sufficiently high levels of decentralization ( $60^{\text {th }}$ percentile). Moreover, it is important to note that the Hansen test for over-identifying restrictions and the test for second-order serial correlation are not rejected, thereby supporting the validity of the model.

\section{Robustness checks}

\subsection{Sensitivity analyses of baseline results}

\footnotetext{
${ }^{24}$ An additional way to further reduce the instrument set would be to only instrument for corruption, decentralization and their interaction. But this has the shortcoming that several other regressors are clearly endogenous to fiscal balances due to the operation of automatic stabilizers over the cycle such as GDP growth and the unemployment rate. If left uncontrolled, endogeneity would bias the results. Therefore, we opt for instrumenting all the regressors with the minimum possible instrument set: $x_{i t-2}$ and $\Delta x_{i t-1}$.
} 
In this section we conduct sensitivity analysis to check the robustness of our baseline results. We begin with Table 5 that introduces subnational govern. expend. as an alternative fiscal decentralization indicator. Remarkably, we find the same pattern observed in Table 4. The main difference is that in the panel with data averaged over 5-year intervals, when using the system GMM estimator, the effect of corruption becomes insignificant at a lower threshold, namely, when expenditure decentralization reaches the $20^{\text {th }}$ percentile (see column 4 ).

\section{[Insert Table 5 about here]}

Table 6 analyzes the robustness of our reference estimation, which is the panel based on 5-year averages using the system GMM estimator. Column 2 presents the results for an alternative tax decentralization measure which is an updated version of Stegarescu's TD1 indicator using OECD information for the data points 2002, 2005 and $2008 .{ }^{25}$ It is remarkable that our main finding regarding the heterogeneity in the effect of fiscal decentralization remains robust to the use of this alternative tax decentralization indicator. As in the baseline analysis, we find that for values of tax decentralization greater than the 50th percentile, the positive marginal effect of corruption becomes insignificant. Hence, the effect of corruption on fiscal deficits is significantly positive when tax decentralization is relatively low, whereas corruption does not significantly affect fiscal balances if a country is highly decentralized.

The remaining columns introduce additional control variables which are thought to affect fiscal deficits in industrialized economies or at least have some effect on it through either fiscal decentralization or corruption. Debt service proxies for interest payments that in the short-run are mostly affected by the existing stock of debt, which have an immediate positive influence on current deficits. The government bond yield at a 10-year maturity tries to capture the fact that debt interest payments above some threshold can generate a permanent increase in the public deficit of sufficient magnitude as to make the stock of public debt unsustainable. The current financial crisis has also shown how important high interest rates on sovereign bonds are as a disciplining mechanism of international investors on governments (acting as a "hard budget constraint”), thus leading to lower future fiscal deficits. The fiscal cost of a banking crisis controls for the effect that financial distress

\footnotetext{
${ }^{25}$ In order to update Stegarescu's TD1 indicator, we calculate the share of sub-central tax revenues on which subcentral government has discretion over tax rates and/or tax bases -a) to $c$ ) components of the OECD classification of taxing power (OECD, 2012a)- as a percentage of general government total tax revenue. Then, we link Stegarescu's data with the new series by applying the growth rate of these ratios to the former to avoid structural change in the series.
} 
and bank bailouts can bring on public sector deficits. As an alternative measure, we also employ a dummy variable for the years where a banking crisis was in place. The dummy federal represents the presence of a federalist constitution implying a legislated division of powers between central and subnational authorities. This variable tries to control for the possibility of overgrazing in federal constitutions due to multiple and sometimes overlapping layers of government. ${ }^{26}$ Government and parliament fragmentation are variables that depend on the efficiency of decentralization according to Persson and Tabellini (2003). The other controls (inflation rate, trade openness, freedom of press, democracy indicator (polity2) and the square of tax decentralization) are factors that can affect fiscal deficits either directly or through their effect on corruption. ${ }^{27}$

The results are reported in columns 3 to 14 of Table 6. In all cases, our baseline results remain fairly robust, while debt service, freedom of press, the banking crisis dummy, democracy and the square term appear with significant coefficients (with a positive sign for the five variables). ${ }^{28}$ In addition, as a further sensitivity analysis we check for the possible influence of outliers by excluding countries one at a time. We also delete observations whose standardized residuals are higher than two in absolute value. The evidence obtained indicates that the results are neither driven by any particular country nor by observations with high residuals. ${ }^{29}$

\section{[Insert Table 6 about here]}

\subsection{Within-country effects: An alternative empirical approach}

The above results can be read from the angle of the effect of decentralization on public deficits depending on countries' corruption levels: decentralization only leads to lower public deficits when the level of corruption is high. This section makes a complementary analysis to further explore this non-linear effect by using an alternative approach. We divide the sample into three groups according to the average level of corruption and then we analyze whether there are significant differences among them regarding the effect of decentralization on public deficits. In this way, corruption is held constant and considered a country feature that only changes very gradually over time, and instead we focus on

\footnotetext{
${ }^{26}$ Indeed, Treisman (2000) provides robust evidence that federal states are more corrupt.

${ }^{27}$ Focusing on a broad cross-section of 64 countries over the period 1980-2000, Lessmann and Markwardt (2010) provide evidence that a free press is necessary for fiscal decentralization to reduce the extent of corruption.

${ }^{28}$ Note that the freedom of press indicator ranges from 0 to 100, where a higher value implies lower press freedom.

${ }^{29}$ We do not report these regressions for space considerations. They are available in the unpublished appendix. Likewise, in the unpublished appendix we also provide the results using annual data. Remarkably, our main findings hold irrespective of the frequency of the data considered.
} 
the variation in fiscal decentralization. ${ }^{30}$ We expect to find heterogeneity in the relationship between this variable and public deficit across the three groups of countries. Decentralization is expected to have more negative effects on public deficits in the group with higher corruption.

A fixed effects model is used in order to focus on "within-country variation”. Thus, by controlling for all time-invariant characteristics, we ask for each group whether countries are more likely to reduce the public deficit as they become more decentralized. More specifically, the equation to estimate is:

$$
\begin{aligned}
& \text { deficit }_{i, t}=\beta_{1} \cdot \text { decentr }_{i, t}+\beta_{2} \cdot \text { decentr } \times \text { int } \_ \text {corr }_{i, t}+ \\
& \beta_{3} \cdot \text { decentr } \times \text { high_corr }{ }_{i, t}+\delta \cdot X_{i, t}+\alpha_{i}+\theta_{t}+\varepsilon_{i, t}
\end{aligned}
$$

where decentr $\times$ int_corr ${ }_{i, t}$ and decentr $\times$ high_corr ${ }_{i, t}$ are the interaction terms between fiscal decentralization and the intermediate and high corruption groups, respectively; $\alpha_{i}$ and $\theta_{t}$ are sets of country and time specific effects and the remaining variables are the same as in Section 4. $\beta_{1}$ estimates the effect of decentralization on public deficits for the "low corruption group" and $\beta_{2}$ and $\beta_{3}$ measure the differences with respect to that group. ${ }^{31}$

Table 7 presents the results obtained from the fixed effects model for our main indicator of fiscal decentralization (subnational tax revenue). Column 1 shows high heterogeneity in the coefficient on tax decentralization across corruption groups for the panel based on annual data. The coefficient is positive and significant for the countries included in the "low corruption group". The "intermediate corruption group" shows a coefficient on tax decentralization significantly different from the previous one, being its value close to zero $(-0.63+0.62=-0.01)$. The coefficient associated with the "high corrupt group" is also significantly different from the reference group and negative $(-0.82+0.62=-$ 0.20). Therefore, there is clear-cut heterogeneity in the effect of tax decentralization across corruption groups. Remarkably, this variable is related to lower deficits only in relatively corrupt countries.

\footnotetext{
${ }^{30}$ We average the indicator ICRG corruption over the period 1984-2010 (all available years). Taking long-term averages makes sense because corruption is a highly persistent institutional characteristic. In this way, we reduce measurement error and avoid doubts about the accuracy of corruption and other government indicators to capture the temporal variation of the data (Treisman, 2007; Arndt and Oman, 2006). The "high corruption group" comprises those countries with average values of corruption higher than the $66^{\text {th }}$ percentile, the "intermediate corruption group" those with average values between the $33^{\text {th }}$ and $66^{\text {th }}$ percentiles, and the "low corruption group" those with values below the $33^{\text {th }}$ percentile. Table 2 shows the countries included in each group. We create a dummy variable for each corruption group.

${ }^{31}$ Hence, the effect of fiscal decentralization on public deficits for the intermediate and high corruption groups are $\left(\beta_{I}\right.$ $\left.+\beta_{2}\right)$ and $\left(\beta_{1}+\beta_{3}\right)$, respectively. The significance level of $\beta_{2}$ and $\beta_{3}$ indicates whether differences with respect to $\beta_{1}$ are statistically significant; therefore, these two coefficients allow us to test the presence of heterogeneity in the effect of fiscal decentralization.
} 
We test whether the previous results are due to the particular classification of countries made with ICRG corruption. Columns 2 to 4 use alternative indicators to create the groups. Column 2 utilizes Corruption Perception Index from Transparency International, while column 3 uses Control of Corruption from the World Bank Governance Indicators. The resulting classifications are very similar to the previous one, despite the use of different sources and period coverage. ${ }^{32}$ Consequently, the results shown in columns 2 and 3 are very consistent with those of column 1. Rather than a perceptionbased indicator, column 4 uses bribe payments, a measure of actual corruption experiences obtained from the Global Corruption Barometer of Transparency International. ${ }^{33}$ Although in this case there are three countries with missing data (Estonia, Slovak Republic and Belgium) and matches with the reference classification are lower (68\%), the results appear highly consistent. The effect of tax decentralization on public deficit is heterogeneous across corruption groups and is only significantly negative for the "high corruption group".

Columns 5 to 8 repeat the above analysis but using data averaged over 5-year intervals. The results remain remarkably robust: the coefficient on tax decentralization is positive for the "low corruption group”, while for the other two groups the coefficient is significantly lower, being very close to zero for the intermediate group and negative for the "high corruption group”.

To sum up, this subsection has shown from a different approach the presence of heterogeneity in the relationship between fiscal decentralization and public deficit depending on the level of corruption. Focusing on "within-country variation", we observe that decentralizing public finances is associated with a reduction in fiscal deficits only in relatively more corrupt countries.

\subsection{Discussion of results}

In this subsection we try to discuss the theoretical mechanisms that could help us to explain the fact that decentralization only leads to lower public deficits when the level of corruption is high, whereas it does not reduce fiscal deficits in a context with low corruption. The line of arguments provided is essentially associated with the fact that in a corrupt environment, fiscal decentralization brings about

\footnotetext{
${ }^{32}$ Due to data availability, we take the average over the years 1996-2009. Matches between classifications made with ICRG indicator and Corruption Perception Index are $87.1 \%$, and between classifications made with ICRG indicator and Control of Corruption are $96.8 \%$.

${ }^{33}$ We take the average over the years 2006-2010.
} 
some disciplining mechanisms such as local accountability or greater interjurisdictional competition that can mitigate the negative effect of corruption on fiscal balances. In contrast, when the government is diligent and honest, fiscal decentralization has less scope to discipline fiscal management, and as a result, the effect on reducing fiscal deficits is less clear.

Arikan (2004) develops a tax-competition model with rent-seeking that predicts that a horizontal rise in the number of jurisdictions that compete for residents and business investment reduces corruption through a fall in the revenue expropriated by rent-seeking bureaucrats. Along similar lines, in Kotsogiannis and Schwager (2006) interjurisdictional competition lowers the possibilities and incentives for rent-seeking on the part of political officials. Establishing hard-budget constraints make local officials responsible for financing the cost of public goods provision, thus acting as a disciplining mechanism of local accountability. However, in their absence, i.e. when soft-budget constraints ${ }^{34}$ and implicit bailout from the central government prevail, local officials will be more prone to pursuing rent-seeking and over-invoicing in the provision of public goods. ${ }^{35}$ In this particular case, the existence of municipal or state elections can serve as an alternative disciplining device to raise local accountability, thus helping to prevent corrupt behavior among local officials.

The rationale for decentralizing tax and expenditure decision-making to the lower levels of government lays in the fact that peer monitoring can take place to directly control agents' behavior (Stiglitz, 1999). Fiscal decentralization aligns spending and funding responsibilities, which improves the efficiency in the provision of public goods. Along these lines, Hindricks and Lockwood (2009) and Weingast (2009) emphasize that greater fiscal autonomy enhances incumbent politicians' performance via electoral accountability. Persson and Tabellini (2000) develop a model on decentralization where political officials try to minimize effort and maximize the probability of re-election. Unlike in a centralized system where bureaucrats are responsible for multiple tasks affecting many jurisdictions, decentralization makes bureaucrats deal with only one task specific to a single locality. By better linking effort and rewards, decentralization improves the performance of political officials, which can be held accountable for their actions by their local constituents.

\footnotetext{
${ }^{34}$ These can result from the lack of tax compliance and the existence of unconditional grants from the central level of government to subnational levels.

${ }^{35}$ Indeed, Weingast (2009) notes that for greater competition to be an effective mechanism for policing corruption, the following must be satisfied: common market conditions, sufficient subnational authority in decision-making and a hard budget constraint.
} 
Empirically this is supported by Khemani (2001) who provides evidence for 14 major Indian states over the period 1960-92 that voters are more vigilant in monitoring the performance of the state government tier in terms of output growth and income inequality compared to the national legislature, where they act more myopically. This thus supports the presence of greater government accountability in elections at the lower levels of government. Finally, focusing on a sample of more than 110 countries over the period 1980-95, Adserá et al. (2003) find that electoral accountability and the exercise of democracy explain more than half of the variability in the levels of government performance and corruption. The reason for this is that informed voters are in a better position to discipline politicians, thereby preventing the latter from engaging in political rent creation and seeking.

\section{Conclusions}

This paper has aimed at providing a practical policy advice regarding a first-order concern in industrialized countries, the public deficit. Throughout the analysis, we have argued that one of the major factors causing public deficits, corruption, may be addressed by decentralizing public finances. Focusing on OECD countries, our article provides extensive empirical support for that proposition. The effect of corruption is non-linear: corruption increases public deficit when fiscal decentralization is low, but as it rises, the effect becomes smaller, being insignificant at sufficiently high levels of decentralization. The result implies heterogeneity in the effect of fiscal decentralization on public deficit, in the sense that decentralizing public finances is more likely to reduce fiscal deficits in relatively more corrupt countries.

The case of Greece clearly illustrates the results. This country has a relatively high level of corruption, being its average level of public deficit over GDP during the period of analysis of almost $7 \%$, the greatest of the sample. Interestingly, Greece is also the most centralized country, with a degree of tax decentralization slightly lower than 1\%. From our findings, it follows that Greece could reduce public deficit by increasing fiscal decentralization. According to the results from the 5-year period panel (Table 4, column 8), for this country the effect of corruption on public deficits is 3.1. By increasing subnational tax revenue to the level of Poland or France (about 10.5\%), the effect would be 2.1, leading to a reduction of one percentage point in the public deficit. Compared to combating corruption, which requires time to dismantle well-established networks of patronage and rent creation and seeking, decentralizing public finances is more feasible to implement, particularly in the short- 
term. Hence, a good policy set would be to combine a program of fight against corruption while increasing fiscal decentralization.

Before making generalizations, a few caveats must be considered. First, we analyze a sample of OECD countries. Conclusions derived from our results cannot be in principle extrapolated to developing countries for a number of reasons. All our countries are economically developed, democratic and with an educated population. Furthermore, despite existing variation in corruption levels, OECD countries are relatively less corrupt when compared to many developing countries. Therefore, further research is necessary to test our findings in a sample of developing and emerging countries. Secondly, the results indicate a stylized fact and suggest but do not prove causality, so interpretations must be made carefully and complemented with the extant literature on fiscal decentralization. In particular, a proper design of the decentralization program is essential, with incentives leading to a responsible fiscal policy (Weingast, 2009). A proper political-institutional framework is also necessary to guarantee accountability and citizen control of subnational governments. Moreover, a cautious interpretation of our findings implies that using fiscal decentralization to mitigate the adverse effects of corruption on public deficits is more advisable when the country starts from low levels of decentralization, as the case of Greece. When the degree of decentralization is already medium or high -as the case of Spain-, the advice of increasing decentralization is much less clear.

Overall, this paper has made a contribution to the literature on decentralization. Our empirical analysis has uncovered substantial heterogeneity in the effect of fiscal decentralization depending on the institutional context. We find that decentralization behaves as a disciplining mechanism that reduces fiscal deficits in a corrupt public environment, but not when corruption is absent. This leads us to an interesting theoretical debate. The result suggests that bringing the government closer to the people is more useful or necessary when public administration is not working properly. In this case, the agent (politicians and public employees) misuses public resources for private gain, and the principal (citizens) must monitor closely the former. This is more feasible when the government is close to the people, since citizens are better informed about local affairs and can revoke corrupt rulers in elections. The argument can be easily extended to related concepts such as political and citizen participation, which is supposed to be more necessary when the government does not work well. Likewise, other dimensions of the performance of countries may be considered from this perspective, such as social policies or environmental quality. 


\section{References}

Adserá, A., Boix, C., Payne, M., 2003. Are you being served? Political accountability and quality of government. The Journal of Law, Economics and Organization 19 (2), 445-490.

Aidt, T.S., 2009. Corruption, institutions, and economic development. Oxford Review of Economic Policy 25(2), 271-291.

Aidt, T.S., Dutta, J., Sena, V., 2008. Governance regimes, corruption and growth: theory and evidence. Journal of Comparative Economics 36(2), 195-220.

Aiken, L., West, S., 1991. Multiple Regression: Testing and Interpreting Interactions. Sage Publications, London.

Arellano, M., Bond, S., 1991. Some tests of specification for panel data: Monte Carlo evidence and an application to employment equations. Review of Economic Studies 58(2), 277-297.

Arellano, M., Bover, O., 1995. Another look at the instrumental variable estimation of error-components models. Journal of Econometrics 68(1), 29-51.

Arikan, G.G., 2004. Fiscal decentralization: A remedy for corruption?. International Tax and Public Finance 11, 175-195.

Arndt, C., Oman, C., 2006. Uses and Abuses of Governance Indicators. OECD Development Centre Studies, Paris.

Baskaran, T., 2010. On the link between fiscal decentralization and public debt in OECD countries. Public Choice 145(3), 351-378.

Baskaran, T., 2012. Tax decentralization and public deficits in OECD countries. Publius: The Journal of Federalism, forthcoming.

Blundell, R., Bond, S., 1998. Initial conditions and moment restrictions in dynamic panel data models. Journal of Econometrics 87(1), 115-143.

Brambor, T., Clark, W., Golder, M., 2006. Understanding interaction models: improving empirical analyses. Political Analysis 14(1), 63-82.

Brennan, G., Buchanan, J., 1980. The Power to Tax: Analytical Foundations of a Fiscal Constitution. Cambridge University Press, Cambridge.

Careaga, M., Weingast, B. R., 2003. Fiscal federalism, good governance, and economic growth in Mexico, in: Rodrik, D. (Ed.), Search of Prosperity: Analytic Narratives on Economic Growth. Princeton University Press, Princeton.

De Mello, L.R., 2000. Fiscal decentralization and intergovernmental fiscal relations: a cross country analysis. World Development 28(2), 365-380.

Depken, C.A., Lafountain, C.L., 2006. Fiscal consequences of public corruption: empirical evidence from state bond ratings. Public Choice 126(1), 75-85.

Dillinger, W., Webb, S., 1999. Fiscal management in federal democracies: Argentina and Brazil. World Bank. Policy Research Working Paper, no. 2121.

Fan, C.S., Lin, C., Treisman, D., 2009. Political decentralization and corruption: evidence from around the world. Journal of Public Economics 93(1-2), 14-34.

Fisman, R., Gatti, R., 2002. Decentralization and corruption: evidence across countries. Journal of Public Economics 83(3), 325-345.

Hindriks, J., Lockwood, B., 2009. Decentralization and electoral accountability: Incentives, separation and voter welfare. European Journal of Political Economy 25, 385-397.

International Monetary Fund, 2012. International Financial Statistics. International Monetary Fund, Washington D.C. 
Ivanyna, M., Shah, A., 2010. Decentralization (localization) and corruption. New cross-country evidence. World Bank. Policy Research Working Paper, no. 5299.

Kaufmann, D., 2010. Can corruption adversely affect public finance in industrialized countries?. Brookings Institution Opinions, April 19.

Kaufmann, D., Kraay, A., Mastruzzi, M., 2010. The worldwide governance indicators: methodology and analytical issues. World Bank. World Bank Policy Research Working Paper, no. 5430.

Khemani, S., 2001. Decentralization and accountability: Are voters more vigilant in local than in national elections?. World Bank Policy Research Working Paper no. 2557, World Bank, Washington D.C.

Kotsogiannis, C., Schwager, R., 2006. Fiscal equalization and Yardstick competition, mimeograph.

Laeven, L., Valencia, F., 2012. Systemic banking crises database: An update. IMF Working Paper. WP/12/163, Washington DC.

Lessmann, C., Markwardt, G., 2010. One size fits all? Decentralization, corruption, and the monitoring of bureaucrats. World Development 38 (4), 631-646.

Mauro, P., 1995. Corruption and growth. Quarterly Journal of Economics, 110(3), 681-712.

Mauro, P., 1997. Why Worry About Corruption?. International Monetary Fund (IMF), Washington, D.C.

Neyapti, B., 2010. Fiscal decentralization and deficits: International evidence. European Journal of Political Economy 26(2), 155-166.

Oates, W.E., 1999. An essay on fiscal federalism. Journal of Economic Literature 37(3), 1120-1149.

Oates, W.E., 2008. On the evolution of fiscal federalism: theory and institutions. National Tax Journal 61(2), 313-334.

OECD, 1999. Taxing Power of State and Local Government. OECD Tax Policy Studies, no. 1.

OECD, 2012a. Fiscal decentralization database. URL: http://www.oecd.org/ctp/fiscalfederalismnetwork /oecdfiscaldecentralisationdatabase.htm [Accessed on 11 June 2012].

OECD, 2012b. Economic Outlook, no. 91, Organization for Economic Cooperation and Development, Paris.

Persson, T., Tabellini, G., 2000. Constitutional determinants of government spending. Mimeograph, Bocconi University.

Persson, T., Tabellini, G., 2003. The Economic Effects of Constitutions. The MIT Press, Cambridge, M.A.

PRS Group, 2012. ICRG methodology. Political Risk Services Group. On-line publication. URL: http://www.prsgroup.com/ICRG_Methodology.aspx [Accessed on 20 June 2012].

Prud'homme, R., 1995. On the dangers of decentralization. World Bank Research Observer 10(2), 201-220.

Rajkumar, A.S., Swaroop, V., 2008. Public spending and outcomes: does governance matter?. Journal of Development Economics 86(1), 96-111.

Rodden, J., 2003. Reviving Leviathan. International Organization 57, 695-729.

Rodden, J., Wibbels, E., 2002. Beyond the fiction of federalism. Macroeconomic management in multitiered systems. World Politics 54(4), 494-531.

Rodríguez-Pose, A., Ezcurra, R., 2011. Is fiscal decentralization harmful for economic growth? Evidence from the OECD countries. Journal of Economic Geography 11(4), 619-643.

Rodríguez-Pose, A., Gill, N., 2003. The global trend towards devolution and its implications. Environment \& Planning C: Government \& Policy 21(3), 333-351.

Roodman, D., 2006. How to do xtabond2: an introduction to "difference" and "system" GMM in Stata. Center for Global Development (Washington, D.C.), Working Paper no. 103.

Roodman, D., 2009. A note on the theme of too many instruments. Oxford Bulletin of Economics and Statistics 71, 135-158. 
Shah, A., 2006. Fiscal decentralization and macroeconomic management. International Tax and Public Finance 13(4), 437-462.

Shleifer, A., Vishny, R., 1993. Corruption. Quarterly Journal of Economics 108, 599-617.

Stegarescu, D., 2005. Public sector decentralization: measurement concepts and recent international trends. Fiscal Studies 26(3), 301-333.

Stegarescu, D., 2009. The effects of economic and political integration on fiscal decentralization: Evidence from OECD countries. Canadian Journal of Economics 42, 694-718.

Stiglitz, J., 1999. Whither reform? Ten years of the transition. Paper Prepared for the Annual World Bank Conference on Development Economics, Washington, D.C., April 28-30.

Tanzi, V., 1999. Governance, corruption and public finance: an overview, in: S. Schiavo-Campo (Ed.) Governance, Corruption and Public Financial Management. Asian Development Bank, Manila.

Tanzi, V., Davoodi, H., 1998. Roads to nowhere: how corruption in public investment hurts growth. International Monetary Fund (IMF), Washington, D.C.

Teorell, J., Samanni, M., Holmberg, S., Rothstein, B., 2011. The quality of government dataset. [version 6 April 2011]. University of Gothenburg, The Quality of Government Institute. URL: http://www.qog.pol.gu.se.

Tiebout, C., 1956. A pure theory of local expenditures. Journal of Political Economy 64(5), 416-424.

Transparency International. Global Corruption Barometer. Several years (2006-2010) URL: http://www.transparency.org/research/gcb/overview.

Treisman, D., 2000. The causes of corruption: A cross-national study. Journal of Public Economics 76 (3), 399-457.

Treisman, D., 2002. Decentralization and the quality of government. University of California, mimeo. URL: http://www.sscnet.ucla.edu/polisci/faculty/treisman/ Pages /unpublishedpapers.html.

Treisman, D., 2007. What have we learned about the causes of corruption from ten years of cross-national empirical research?. Annual Review of Political Science 10, 211-244.

Wei, S.J., 1997a. Why is corruption so much more taxing than tax? Arbitrariness kills. National Bureau of Economic Research (NBER), Cambridge, Massachusetts.

Wei, S.J., 1997b. How taxing is corruption on international investors?. NBER Working Paper, no. 6255.

Weingast, B.R., 1995. The economic role of political institutions: market-preserving federalism and economic development. Journal of Law, Economics and Organization 11(1), 1-31.

Weingast, B.R., 2009. Second generation fiscal federalism: the implications of fiscal incentives. Journal of Urban Economics 65(3), 279-293.

World Bank, 2011. World Development Indicators 2011 Database. World Bank, Washington, D.C.

World Bank, 2012a. Anticorruption. Costs and consequences of corruption. World Bank, Washington D.C. URL: http://go.worldbank.org/BVKN7CIK60 [Accessed on 25 June 2012].

World Bank, 2012b. Anticorruption. Corruption and fiscal stability. World Bank, Washington D.C. URL: http://go.worldbank.org/007SFZXAU0 [Accessed on 25 June 2012]. 


\section{Tables and figures}

Table 1

Descriptive comparisons among country-pairs

\begin{tabular}{|c|c|c|c|}
\hline Country & $\begin{array}{c}\text { ICRG } \\
\text { corruption }\end{array}$ & $\begin{array}{c}\text { Fiscal decentralization } \\
\text { (subnational tax revenue) }\end{array}$ & Public deficit \\
\hline \multicolumn{4}{|c|}{ Two relatively corrupt countries } \\
\hline $\begin{array}{l}\text { Greece } \\
\text { vs. }\end{array}$ & 2.1 & 0.9 & 6.9 \\
\hline Poland & 2.4 & 10.5 & 4.6 \\
\hline \multicolumn{4}{|c|}{ Two relatively non-corrupt countries } \\
\hline $\begin{array}{c}\text { The Netherlands } \\
\text { vs. }\end{array}$ & 0.4 & 3.0 & 2.6 \\
\hline Canada & 0.4 & 46.4 & 2.7 \\
\hline
\end{tabular}

Notes: The variables represent the average of available data over the period 1986-2010. The definitions of the variables can be found in Appendix I.

Table 2

Corruption, fiscal decentralization and public deficit

\begin{tabular}{|c|c|c|c|}
\hline Corruption groups/ Countries & $\begin{array}{l}\text { ICRG } \\
\text { corruption }\end{array}$ & $\begin{array}{c}\text { Fiscal decentralization } \\
\text { (subnational tax revenue) } \\
\text { Averages by group }\end{array}$ & Public deficit \\
\hline High corruption & 2.43 & 7.48 & 3.98 \\
\hline $\begin{array}{l}\text { Low tax decentralization } \\
\text { Greece, The Slovak Republic, The Czech } \\
\text { Republic, Hungary and Israel. } \\
\text { - High tax decentralization }\end{array}$ & 2.20 & 3.31 & 5.73 \\
\hline $\begin{array}{l}\text { Slovenia, Italy, Poland, Estonia, and } \\
\text { Korea (Rep.). }\end{array}$ & 2.67 & 11.64 & 2.22 \\
\hline Intermediate corruption & 1.57 & 14.13 & 3.30 \\
\hline $\begin{array}{l}\text { Low tax decentralization } \\
\text { Ireland, Portugal, The United Kingdom, } \\
\text { Belgium and France. } \\
\text { - High tax decentralization }\end{array}$ & 1.61 & 6.13 & 3.64 \\
\hline $\begin{array}{l}\text { Austria, Spain, Australia, Japan and The } \\
\text { United States. }\end{array}$ & 1.53 & 22.13 & 2.96 \\
\hline Low corruption & 0.45 & 23.23 & 0.08 \\
\hline $\begin{array}{l}\text { Low tax decentralization } \\
\text { The Netherlands, Luxembourg, New } \\
\text { Zealand, Norway, Finland and Iceland. } \\
\text { - High tax decentralization }\end{array}$ & 0.36 & 12.61 & -0.99 \\
\hline $\begin{array}{l}\text { Germany, Denmark, Sweden, Switzerland } \\
\text { and Canada. }\end{array}$ & 0.55 & 35.97 & 1.35 \\
\hline
\end{tabular}

Notes: The variables represent the average of available data over the period 1986-2010. The definitions of the variables can be found in Appendix I. 
Table 3

Cross-section analysis

\begin{tabular}{|c|c|c|c|c|c|c|c|}
\hline & & Depe & ndent varia & ble is publi & cit over $G$ & & \\
\hline & & Tax & decentralizi & tion & Expend & Ire decent & alization \\
\hline & (1) & (2) & (3) & (4) & (5) & (6) & (7) \\
\hline ICRG corruption & $1.295^{* *}$ & 0.812 & $2.268 * *$ & $2.702 * * *$ & 0.872 & $2.5^{*}$ & $3.926 * * *$ \\
\hline & $(0.56)$ & $(0.71)$ & $(0.86)$ & $(0.9)$ & $(0.74)$ & $(1.25)$ & $(1.39)$ \\
\hline Fiscal decentralization & & $-0.071^{*}$ & 0.035 & 0.068 & -0.04 & 0.018 & 0.064 \\
\hline & & $(0.04)$ & $(0.06)$ & $(0.06)$ & $(0.03)$ & $(0.04)$ & $(0.04)$ \\
\hline Corruption x Fiscal & & & $-0.135 * *$ & -0.091 & & -0.061 & $-0.082 *$ \\
\hline decent. & & & $(0.06)$ & $(0.06)$ & & $(0.04)$ & $(0.05)$ \\
\hline Total government & -0.078 & -0.105 & -0.137 & & -0.101 & -0.124 & \\
\hline revenue & $(0.1)$ & $(0.1)$ & $(0.1)$ & & $(0.1)$ & $(0.11)$ & \\
\hline Growth GDP pc & $-1.587 * * *$ & $-1.708 * * *$ & $-1.449 * * *$ & & $-1.5 * * *$ & $-1.17^{* *}$ & \\
\hline & $(0.41)$ & $(0.36)$ & $(0.34)$ & & $(0.38)$ & $(0.41)$ & \\
\hline Unemployment rate & $0.315^{*}$ & $0.328 * *$ & $0.267 * *$ & & $0.339 * *$ & $0.309 * *$ & \\
\hline & $(0.16)$ & $(0.15)$ & $(0.12)$ & & $(0.16)$ & $(0.14)$ & \\
\hline Ln GDP pc & -0.311 & -0.122 & 0.093 & & -0.195 & -0.167 & \\
\hline & (1.03) & $(0.98)$ & $(0.87)$ & & (1.06) & (1.06) & \\
\hline Population & 0.004 & $0.009 *$ & $0.02 * *$ & & 0.006 & $0.01 *$ & \\
\hline & $(0.004)$ & $(0.004)$ & $(0.01)$ & & $(0.004)$ & $(0.005)$ & \\
\hline R-squared & 0.53 & 0.58 & 0.65 & 0.29 & 0.55 & 0.58 & 0.31 \\
\hline Number of obs. & 31 & 31 & 31 & 31 & 28 & 28 & 28 \\
\hline Marginal effects of cor & ption for dif & ent percent & iles of fisca & decentrali & & & \\
\hline Pct 10 (Tax: 2.1) (Exp. & 2.7) & & $1.98 * *$ & $2.51 * * *$ & & $1.73^{*}$ & $2.88 * * *$ \\
\hline & & & $(0.787)$ & $(0.835)$ & & $(0.848)$ & $(0.91)$ \\
\hline Pct 20 (Tax: 4.8) (Exp. & 7.5) & & $1.62 * *$ & $2.26 * * *$ & & $1.44^{*}$ & $2.49 * * *$ \\
\hline & & & $(0.71)$ & $(0.772)$ & & $(0.745)$ & $(0.77)$ \\
\hline Pct 30 (Tax: 5.8) (Exp. & & & $1.49 * *$ & $2.18 * * *$ & & 0.98 & $1.87 * * *$ \\
\hline & & & $(0.69)$ & $(0.757)$ & & $(0.682)$ & $(0.648)$ \\
\hline Pct 40 (Tax: 7.7) (Exp. & 7.9) & & $1.23 *$ & $2 * *$ & & 0.81 & $1.64^{* *}$ \\
\hline & & & $(0.66)$ & $(0.739)$ & & $(0.697)$ & $(0.646)$ \\
\hline Pct 50 (Tax: 10.5) (Exp & 30.4) & & 0.85 & $1.75^{* *}$ & & 0.66 & $1.44^{* *}$ \\
\hline & & & $(0.651)$ & $(0.744)$ & & $(0.727)$ & $(0.666)$ \\
\hline Pct 60 (Tax: 17.1) (Exp & 32.6) & & -0.04 & 1.15 & & 0.52 & $1.25 *$ \\
\hline & & & $(0.777)$ & $(0.889)$ & & $(0.765)$ & $(0.7)$ \\
\hline Pct 70 (Tax: 20.8) (Exp & 37.1) & & -0.54 & 0.81 & & 0.25 & 0.88 \\
\hline & & & $(0.913)$ & (1.029) & & $(0.868)$ & $(0.803)$ \\
\hline Pct 80 (Tax: 28.3) (Exp & 43.8) & & -1.54 & 0.14 & & -0.15 & 0.34 \\
\hline & & & $(1.253)$ & (1.373) & & $(1.067)$ & $(1.017)$ \\
\hline Pct 90 (Tax: 33.1) (Exp & $55.1)$ & & -2.19 & -0.3 & & -0.84 & -0.59 \\
\hline & & & $(1.502)$ & $(1.626)$ & & (1.473) & $(1.462)$ \\
\hline
\end{tabular}

Notes: The proxies for tax and expenditure decentralization are subnational tax revenue and subnational govern. expend., respectively. The variables represent the average of available data over the period 1986-2010. The estimations include a constant term, which is omitted for space considerations. All regressions are estimated with OLS. Robust standard errors are in parentheses. ${ }^{*}, * *$ and $* * *$ denote significance at the 10,5 and $1 \%$ levels, respectively. Percentiles of tax and expenditure decentralization are calculated for average values over the period 1986-2010. The definitions of the variables can be found in Appendix I. The list of countries included in the sample is shown in Table 2. 
Table 4

Panel data analysis. Tax decentralization

\begin{tabular}{|c|c|c|c|c|c|c|c|c|}
\hline & \multicolumn{8}{|c|}{ Dependent variable is public deficit over GDP } \\
\hline & \multicolumn{4}{|c|}{ Annual data } & \multicolumn{4}{|c|}{ 5-year average data } \\
\hline & \multicolumn{2}{|c|}{$O L S$} & \multicolumn{2}{|c|}{ System GMM estimator } & \multicolumn{2}{|c|}{$O L S$} & \multicolumn{2}{|c|}{ System GMM estimator } \\
\hline & (1) & $(2)$ & (3) & $(4)$ & (5) & (6) & $(7)$ & $(8)$ \\
\hline ICRG corruption & $\begin{array}{c}0.801^{* * *} \\
(0.16)\end{array}$ & $\begin{array}{c}1.391^{* * * *} \\
(0.2)\end{array}$ & $\begin{array}{l}0.857^{*} \\
(0.48)\end{array}$ & $\begin{array}{c}1.413^{* * *} \\
(0.47)\end{array}$ & $\begin{array}{c}1.099 * * * \\
(0.31)\end{array}$ & $\begin{array}{c}1.674 * * * \\
(0.34)\end{array}$ & $\begin{array}{l}1.048^{*} \\
(0.62)\end{array}$ & $\begin{array}{c}1.516^{* * *} \\
(0.53)\end{array}$ \\
\hline Tax decentralization & & $\begin{array}{l}0.016 \\
(0.01)\end{array}$ & & $\begin{array}{l}0.027 \\
(0.04)\end{array}$ & & $\begin{array}{l}0.019 \\
(0.03)\end{array}$ & & $\begin{array}{l}0.005 \\
(0.04)\end{array}$ \\
\hline $\begin{array}{l}\text { Corruption x Tax } \\
\text { decent. }\end{array}$ & & $\begin{array}{c}-0.058 * * * \\
(0.01)\end{array}$ & & $\begin{array}{c}-0.055^{*} \\
(0.03)\end{array}$ & & $\begin{array}{c}-0.075^{* * *} \\
(0.02)\end{array}$ & & $\begin{array}{c}-0.051 * \\
(0.03)\end{array}$ \\
\hline $\begin{array}{l}\text { Total government } \\
\text { revenue }\end{array}$ & $\begin{array}{c}-0.042 * \\
(0.02)\end{array}$ & $\begin{array}{c}-0.072 * * * \\
(0.02)\end{array}$ & $\begin{array}{l}-0.035 \\
(0.07)\end{array}$ & $\begin{array}{l}-0.06 \\
(0.06)\end{array}$ & $\begin{array}{l}-0.054 \\
(0.05)\end{array}$ & $\begin{array}{c}-0.086^{*} \\
(0.05)\end{array}$ & $\begin{array}{l}0.062 \\
(0.16)\end{array}$ & $\begin{array}{l}0.046 \\
(0.14)\end{array}$ \\
\hline Growth GDP pc & $\begin{array}{c}-0.482 * * * \\
(0.08)\end{array}$ & $\begin{array}{c}-0.494 * * * \\
(0.08)\end{array}$ & $\begin{array}{c}-0.582^{* * *} \\
(0.13)\end{array}$ & $\begin{array}{c}-0.536 * * * \\
(0.11)\end{array}$ & $\begin{array}{c}-0.882 * * * \\
(0.18)\end{array}$ & $\begin{array}{c}-0.911^{* * *} \\
(0.17)\end{array}$ & $\begin{array}{l}-0.425 \\
(0.31)\end{array}$ & $\begin{array}{c}-0.642^{* *} \\
(0.28)\end{array}$ \\
\hline Unemployment rate & $\begin{array}{c}0.328 * * * \\
(0.04)\end{array}$ & $\begin{array}{c}0.301 * * * \\
(0.04)\end{array}$ & $\begin{array}{c}0.446 * * * \\
(0.13)\end{array}$ & $\begin{array}{c}0.363 * * * \\
(0.11)\end{array}$ & $\begin{array}{c}0.271^{* * * *} \\
(0.08)\end{array}$ & $\begin{array}{c}0.256 * * * \\
(0.07)\end{array}$ & $\begin{array}{l}0.327 * \\
(0.17)\end{array}$ & $\begin{array}{c}0.318 * * \\
(0.14)\end{array}$ \\
\hline Ln GDP pc & $\begin{array}{c}-1.399 * * * \\
(0.33)\end{array}$ & $\begin{array}{c}-1.168 * * * \\
(0.34)\end{array}$ & $\begin{array}{l}-1.163 \\
(0.73)\end{array}$ & $\begin{array}{l}-1.08 \\
(0.75)\end{array}$ & $\begin{array}{c}-1.273^{* *} \\
(0.6)\end{array}$ & $\begin{array}{c}-1.055^{*} \\
(0.61)\end{array}$ & $\begin{array}{l}-1.023 \\
(0.83)\end{array}$ & $\begin{array}{l}-1.095 \\
(0.77)\end{array}$ \\
\hline Population & $\begin{array}{c}0.009 * * * \\
(0.002)\end{array}$ & $\begin{array}{c}0.016 * * * \\
(0.002)\end{array}$ & $\begin{array}{c}0.009 * * * \\
(0.003)\end{array}$ & $\begin{array}{c}0.014 * * * \\
(0.005)\end{array}$ & $\begin{array}{c}0.007^{* *} \\
(0.004)\end{array}$ & $\begin{array}{c}0.017 * * * \\
(0.004)\end{array}$ & $\begin{array}{l}0.012 \\
(0.01)\end{array}$ & $\begin{array}{c}0.019 * * \\
(0.01)\end{array}$ \\
\hline Arellano-Bond test fo & $\mathrm{R}(2)$ & & 0.07 & 0.11 & & & 0.57 & 0.73 \\
\hline $\begin{array}{l}\text { Hansen test of overid } \\
\text { R-squared }\end{array}$ & $\begin{array}{ll}\text { st. } & \\
& 0.45\end{array}$ & 0.48 & 1.00 & 1.00 & 0.47 & 0.52 & 0.87 & 1.00 \\
\hline Number of obs. & 636 & 632 & 636 & 632 & 142 & 142 & 142 & 142 \\
\hline \multicolumn{9}{|c|}{ Marginal effects of corruption for different percentiles of fiscal decentralization } \\
\hline Pct 10 (Tax: 2.1) & & $\begin{array}{c}1.27 * * * \\
(0.189)\end{array}$ & & $\begin{array}{l}1.3^{* * *} \\
(0.442)\end{array}$ & & $\begin{array}{l}1.52 * * * \\
(0.321)\end{array}$ & & $\begin{array}{l}1.41^{* * *} \\
(0.521)\end{array}$ \\
\hline Pct 20 (Tax: 4.8) & & $\begin{array}{l}1.11^{* * *} \\
(0.178)\end{array}$ & & $\begin{array}{l}1.15^{* * *} \\
(0.415)\end{array}$ & & $\begin{array}{l}1.31^{* * *} \\
(0.302)\end{array}$ & & $\begin{array}{l}1.27 * * \\
(0.52)\end{array}$ \\
\hline Pct 30 (Tax: 5.8) & & $\begin{array}{l}1.06^{* * *} \\
(0.175)\end{array}$ & & $\begin{array}{l}1.1^{* * *} \\
(0.41)\end{array}$ & & $\begin{array}{l}1.24 * * * \\
(0.297)\end{array}$ & & $\begin{array}{l}1.23 * * \\
(0.523)\end{array}$ \\
\hline Pct 40 (Tax: 7.7) & & $\begin{array}{c}0.94 * * * \\
(0.172)\end{array}$ & & $\begin{array}{l}0.99 * * \\
(0.405)\end{array}$ & & $\begin{array}{l}1.09 * * * \\
(0.292)\end{array}$ & & $\begin{array}{l}1.13 * * \\
(0.534)\end{array}$ \\
\hline Pct 50 (Tax: 10.5) & & $\begin{array}{c}0.78^{* * *} \\
(0.173)\end{array}$ & & $\begin{array}{l}0.84^{* *} \\
(0.415)\end{array}$ & & $\begin{array}{c}0.88 * * * \\
(0.294)\end{array}$ & & $\begin{array}{c}0.98^{*} \\
(0.561)\end{array}$ \\
\hline Pct 60 (Tax: 17.1) & & $\begin{array}{l}0.39 * * \\
(0.197)\end{array}$ & & $\begin{array}{c}0.48 \\
(0.505)\end{array}$ & & $\begin{array}{c}0.38 \\
(0.338)\end{array}$ & & $\begin{array}{c}0.65 \\
(0.664)\end{array}$ \\
\hline Pct 70 (Tax: 20.8) & & $\begin{array}{c}0.18 \\
(0.221)\end{array}$ & & $\begin{array}{c}0.28 \\
(0.584)\end{array}$ & & $\begin{array}{c}0.1 \\
(0.382)\end{array}$ & & $\begin{array}{c}0.46 \\
(0.741)\end{array}$ \\
\hline Pct 80 (Tax: 28.3) & & $\begin{array}{l}-0.26 \\
(0.284)\end{array}$ & & $\begin{array}{c}-0.13 \\
(0.771)\end{array}$ & & $\begin{array}{c}-0.46 \\
(0.493)\end{array}$ & & $\begin{array}{c}0.09 \\
(0.917)\end{array}$ \\
\hline Pct 90 (Tax: 33.1) & & $\begin{array}{c}-0.54 \\
(0.331)\end{array}$ & & $\begin{array}{c}-0.4 \\
(0.908)\end{array}$ & & $\begin{array}{c}-0.82 \\
(0.576)\end{array}$ & & $\begin{array}{c}-0.16 \\
(1.044)\end{array}$ \\
\hline
\end{tabular}

Notes: The proxy for tax decentralization is subnational tax revenue. The period analyzed is 1986-2010. The estimations include a constant term and period dummies, which are omitted for space considerations. Robust standard errors are in parentheses. *, ** and *** denote significance at the 10, 5 and 1\% levels, respectively. Percentiles of tax decentralization are calculated for average values over the period 1986-2010. The definitions of the variables can be found in Appendix I. The list of countries included in the sample is shown in Table 2. Regressions 1, 2, 5 and 6 are estimated with OLS. Regressions 3, 4, 7 and 8 are estimated with the one-step system GMM estimator using the STATA program xtabond (Roodman, 2006), with the orthogonal deviations transformation applied. For the first-difference equation, the second lag of explanatory variables (all treated as endogenous) are used as instruments. For the level equation, the lagged first-difference of explanatory variables are used as instruments. The exogenous variables are the period dummies. 
Table 5

Panel data analysis. Expenditure decentralization

Dependent variable is public deficit over GDP

\begin{tabular}{|c|c|c|c|c|}
\hline & \multicolumn{2}{|c|}{ Annual data } & \multicolumn{2}{|c|}{ 5-year average data } \\
\hline & $\begin{array}{c}O L S \\
(1)\end{array}$ & $\begin{array}{c}\text { System GMM estimator } \\
(2) \\
\end{array}$ & $\begin{array}{l}O L S \\
(3)\end{array}$ & $\begin{array}{c}\text { System GMM estimator } \\
(4)\end{array}$ \\
\hline Corruption & $\begin{array}{c}2.562 * * * \\
(0.29)\end{array}$ & $\begin{array}{c}2.566 * * * \\
(0.65)\end{array}$ & $\begin{array}{c}2.979 * * * \\
(0.53)\end{array}$ & $\begin{array}{l}2.034^{*} \\
(1.13)\end{array}$ \\
\hline Expenditure decentralization & $\begin{array}{c}0.042^{* * *} \\
(0.01)\end{array}$ & $\begin{array}{c}0.044^{*} \\
(0.03)\end{array}$ & $\begin{array}{l}0.039 \\
(0.02)\end{array}$ & $\begin{array}{l}0.032 \\
(0.04)\end{array}$ \\
\hline $\begin{array}{l}\text { Corruption x Expenditure } \\
\text { decent. }\end{array}$ & $\begin{array}{c}-0.068^{* * *} \\
(0.01)\end{array}$ & $\begin{array}{c}-0.064^{* * *} \\
(0.02)\end{array}$ & $\begin{array}{c}-0.074 * * * \\
(0.02)\end{array}$ & $\begin{array}{l}-0.056^{*} \\
(0.03)\end{array}$ \\
\hline Total government revenue & $\begin{array}{c}-0.112^{* * *} \\
(0.03)\end{array}$ & $\begin{array}{l}-0.101 \\
(0.08)\end{array}$ & $\begin{array}{l}-0.089 \\
(0.06)\end{array}$ & $\begin{array}{l}-0.079 \\
(0.11)\end{array}$ \\
\hline Growth GDP pc & $\begin{array}{c}-0.418^{* * *} \\
(0.08)\end{array}$ & $\begin{array}{c}-0.397^{* * *} \\
(0.09)\end{array}$ & $\begin{array}{c}-0.675^{* * *} \\
(0.18)\end{array}$ & $\begin{array}{l}-0.428 \\
(0.27)\end{array}$ \\
\hline Unemployment rate & $\begin{array}{c}0.264^{* * *} \\
(0.05)\end{array}$ & $\begin{array}{c}0.31^{* * *} \\
(0.11)\end{array}$ & $\begin{array}{c}0.186^{* *} \\
(0.08)\end{array}$ & $\begin{array}{l}0.383^{*} \\
(0.22)\end{array}$ \\
\hline Ln GDP pc & $\begin{array}{c}-1.538^{* * *} \\
(0.35)\end{array}$ & $\begin{array}{l}-0.959 \\
(0.82)\end{array}$ & $\begin{array}{c}-1.319 * * \\
(0.65)\end{array}$ & $\begin{array}{l}-0.775 \\
(0.93)\end{array}$ \\
\hline Population & $\begin{array}{c}0.012 * * * \\
(0.002)\end{array}$ & $\begin{array}{c}0.011^{* * *} \\
(0.003)\end{array}$ & $\begin{array}{c}0.014^{* * *} \\
(0.004)\end{array}$ & $\begin{array}{c}0.014^{* * *} \\
(0.01)\end{array}$ \\
\hline $\begin{array}{l}\text { Arellano-Bond test for AR(2) } \\
\text { Hansen test of overid. rest. }\end{array}$ & & $\begin{array}{l}0.07 \\
1.00\end{array}$ & & $\begin{array}{l}0.41 \\
1.00\end{array}$ \\
\hline $\begin{array}{l}\text { R-squared } \\
\text { Number of obs. }\end{array}$ & $\begin{array}{l}0.54 \\
492\end{array}$ & 492 & $\begin{array}{l}0.54 \\
118\end{array}$ & 118 \\
\hline Marginal effects of corruption & fferent perc & of fiscal decentralization & & \\
\hline Pct 10 (Exp.: 12.7) & $\begin{array}{l}1.7^{* * *} \\
(0.209)\end{array}$ & $\begin{array}{c}1.75^{* * * *} \\
(0.48)\end{array}$ & $\begin{array}{c}2.03^{* * *} \\
(0.388)\end{array}$ & $\begin{array}{l}1.32 * \\
(0.8)\end{array}$ \\
\hline Pct 20 (Еxp.: 17.5) & $\begin{array}{l}1.38 * * * \\
(0.186)\end{array}$ & $\begin{array}{l}1.44^{* * *} \\
(0.429)\end{array}$ & $\begin{array}{l}1.68^{* * *} \\
(0.348)\end{array}$ & $\begin{array}{c}1.05 \\
(0.686)\end{array}$ \\
\hline Pct 30 (Exp.: 25) & $\begin{array}{c}0.87^{* * *} \\
(0.163)\end{array}$ & $\begin{array}{l}0.96 * * \\
(0.378)\end{array}$ & $\begin{array}{l}1.11^{* * *} \\
(0.313)\end{array}$ & $\begin{array}{c}0.63 \\
(0.532)\end{array}$ \\
\hline Pct 40 (Ехр.: 27.9) & $\begin{array}{c}0.67 * * * \\
(0.16)\end{array}$ & $\begin{array}{l}0.78 * * \\
(0.37)\end{array}$ & $\begin{array}{l}0.9 * * * \\
(0.311)\end{array}$ & $\begin{array}{c}0.47 \\
(0.487)\end{array}$ \\
\hline Pct 50 (Еxp.: 30.4) & $\begin{array}{c}0.51^{* * *} \\
(0.159)\end{array}$ & $\begin{array}{l}0.62^{*} \\
(0.369)\end{array}$ & $\begin{array}{l}0.72 * * \\
(0.315)\end{array}$ & $\begin{array}{c}0.33 \\
(0.456)\end{array}$ \\
\hline Pct 60 (Еxp.: 32.6) & $\begin{array}{l}0.36^{* *} \\
(0.161)\end{array}$ & $\begin{array}{c}0.48 \\
(0.373)\end{array}$ & $\begin{array}{c}0.55^{*} \\
(0.322)\end{array}$ & $\begin{array}{c}0.2 \\
(0.437)\end{array}$ \\
\hline Pct 70 (Еxp.: 37.1) & $\begin{array}{l}0.05 \\
(0.17)\end{array}$ & $\begin{array}{c}0.19 \\
(0.393)\end{array}$ & $\begin{array}{c}0.22 \\
(0.348)\end{array}$ & $\begin{array}{l}-0.05 \\
(0.426)\end{array}$ \\
\hline Pct 80 (Ехр.: 43.8) & $\begin{array}{l}-0.4 * * \\
(0.195)\end{array}$ & $\begin{array}{l}-0.24 \\
(0.449)\end{array}$ & $\begin{array}{l}-0.28 \\
(0.406)\end{array}$ & $\begin{array}{l}-0.42 \\
(0.48)\end{array}$ \\
\hline Pct 90 (Еxp.: 55.1) & $\begin{array}{c}-1.17 * * * \\
(0.259)\end{array}$ & $\begin{array}{l}-0.97 \\
(0.59)\end{array}$ & $\begin{array}{l}-1.13^{* *} \\
(0.541)\end{array}$ & $\begin{array}{l}-1.06 \\
(0.696)\end{array}$ \\
\hline
\end{tabular}

Notes: The proxy for expenditure decentralization is subnational govern. expend. The period analyzed is 1986-2010. The estimations include a constant term and period dummies, which are omitted for space considerations. Robust standard errors are in parentheses. *, ** and *** denote significance at the 10, 5 and 1\% levels, respectively. Percentiles of expenditure decentralization are calculated for average values over the period 1986 . 2010. The definitions of the variables can be found in Appendix I. The list of countries included in the sample is shown in Table 2. Regressions 1 and 3 are estimated with OLS. Regressions 2 and 4 are estimated with the one-step system GMM estimator using the STATA program xtabond (Roodman, 2006), with the orthogonal deviations transformation applied. For the first-difference equation, the second lag of explanatory variables (all treated as endogenous) are used as instruments. For the level equation, the lagged first-difference of explanatory variables are used as instruments. The exogenous variables are the period dummies. 


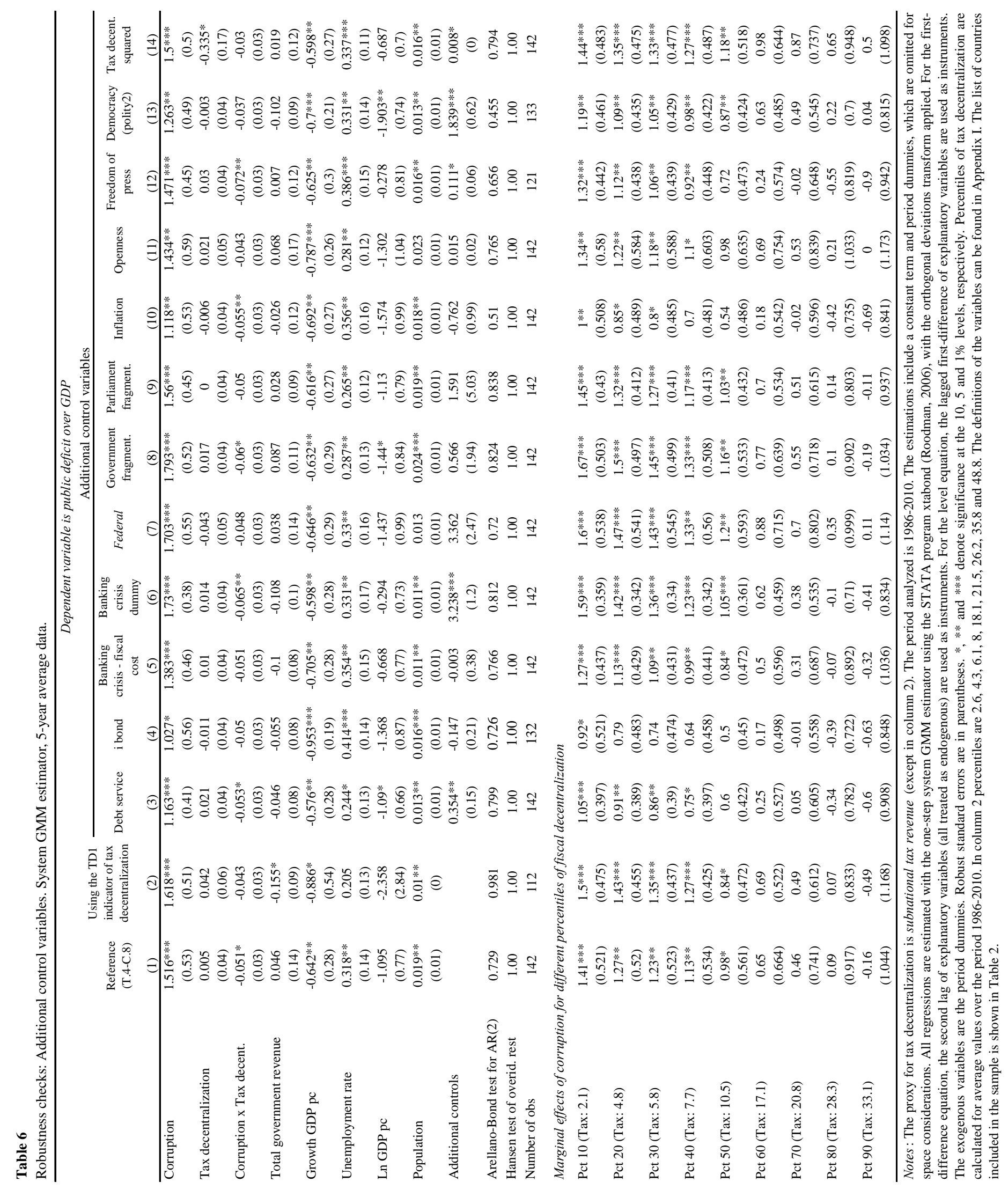


Table 7

Within-country variations.

Dependent variable is public deficit over GDP

\begin{tabular}{|c|c|c|c|c|c|c|c|c|}
\hline \multirow[b]{2}{*}{ Corruption indicator } & \multicolumn{4}{|c|}{ Annual data } & \multicolumn{4}{|c|}{ 5-year average data } \\
\hline & $\begin{array}{l}\text { ICRG } \\
(1)\end{array}$ & $\begin{array}{l}\text { TI } \\
(2)\end{array}$ & $\begin{array}{c}\text { WBGI } \\
\text { (3) }\end{array}$ & $\begin{array}{l}\text { GCB } \\
\text { (4) }\end{array}$ & $\begin{array}{l}\text { ICRG } \\
(5)\end{array}$ & $\begin{array}{c}\text { TI } \\
(6)\end{array}$ & $\begin{array}{c}\text { WBGI } \\
(7)\end{array}$ & $\begin{array}{l}\text { GCB } \\
(8)\end{array}$ \\
\hline Tax decentralization & $\begin{array}{c}0.62^{* * *} \\
(0.13)\end{array}$ & $\begin{array}{c}0.549 * * * \\
(0.12)\end{array}$ & $\begin{array}{c}0.642^{* * *} \\
(0.13)\end{array}$ & $\begin{array}{c}0.665^{* * *} \\
(0.15)\end{array}$ & $\begin{array}{c}0.593^{* *} \\
(0.27)\end{array}$ & $\begin{array}{c}0.526^{* *} \\
(0.25)\end{array}$ & $\begin{array}{c}0.607 * * \\
(0.27)\end{array}$ & $\begin{array}{c}0.721^{* *} \\
(0.32)\end{array}$ \\
\hline Tax decent x Interm. corruption & $\begin{array}{c}-0.632 * * * \\
(0.13)\end{array}$ & $\begin{array}{c}-0.564 * * * \\
(0.13)\end{array}$ & $\begin{array}{c}-0.656^{* * *} \\
(0.14)\end{array}$ & $\begin{array}{c}-0.622 * * * \\
(0.15)\end{array}$ & $\begin{array}{c}-0.588^{* *} \\
(0.27)\end{array}$ & $\begin{array}{c}-0.525 * * \\
(0.25)\end{array}$ & $\begin{array}{c}-0.605^{* *} \\
(0.27)\end{array}$ & $\begin{array}{c}-0.746 * * \\
(0.33)\end{array}$ \\
\hline Tax decent $\mathrm{x}$ High corruption & $\begin{array}{c}-0.822 * * * \\
(0.14)\end{array}$ & $\begin{array}{c}-0.753^{* * *} \\
(0.13)\end{array}$ & $\begin{array}{c}-0.845^{* * *} \\
(0.14)\end{array}$ & $\begin{array}{c}-0.757 * * * \\
(0.15)\end{array}$ & $\begin{array}{c}-0.669 * * \\
(0.32)\end{array}$ & $\begin{array}{c}-0.604^{*} \\
(0.31)\end{array}$ & $\begin{array}{c}-0.685^{* *} \\
(0.32)\end{array}$ & $\begin{array}{c}-0.777 * * \\
(0.33)\end{array}$ \\
\hline Total government revenue & $\begin{array}{c}-0.162 * * * \\
(0.05)\end{array}$ & $\begin{array}{c}-0.161^{* * *} \\
(0.05)\end{array}$ & $\begin{array}{c}-0.162^{* * *} \\
(0.05)\end{array}$ & $\begin{array}{c}-0.132 * * \\
(0.05)\end{array}$ & $\begin{array}{l}-0.148 \\
(0.11)\end{array}$ & $\begin{array}{l}-0.145 \\
(0.11)\end{array}$ & $\begin{array}{l}-0.146 \\
(0.11)\end{array}$ & $\begin{array}{l}-0.052 \\
(0.11)\end{array}$ \\
\hline Growth GDP pc & $\begin{array}{c}-0.288 * * * \\
(0.06)\end{array}$ & $\begin{array}{c}-0.288^{* * *} \\
(0.06)\end{array}$ & $\begin{array}{c}-0.287 * * * \\
(0.06)\end{array}$ & $\begin{array}{c}-0.295^{* * *} \\
(0.06)\end{array}$ & $\begin{array}{c}-0.428 * * \\
(0.19)\end{array}$ & $\begin{array}{c}-0.423 * * \\
(0.19)\end{array}$ & $\begin{array}{c}-0.427 * * \\
(0.19)\end{array}$ & $\begin{array}{c}-0.674 * * * \\
(0.22)\end{array}$ \\
\hline Unemployment rate & $\begin{array}{c}0.45^{* * *} \\
(0.05)\end{array}$ & $\begin{array}{c}0.44^{* * *} \\
(0.05)\end{array}$ & $\begin{array}{c}0.451^{* * *} \\
(0.05)\end{array}$ & $\begin{array}{c}0.508 * * * \\
(0.05)\end{array}$ & $\begin{array}{c}0.441^{* * *} \\
(0.11)\end{array}$ & $\begin{array}{c}0.428 * * * \\
(0.11)\end{array}$ & $\begin{array}{c}0.441^{* * *} \\
(0.11)\end{array}$ & $\begin{array}{c}0.312 * * \\
(0.12)\end{array}$ \\
\hline Ln GDP pc & $\begin{array}{l}2.142 \\
(1.43)\end{array}$ & $\begin{array}{l}1.874 \\
(1.42)\end{array}$ & $\begin{array}{c}2.05 \\
(1.43)\end{array}$ & $\begin{array}{c}3.527^{* *} \\
(1.65)\end{array}$ & $\begin{array}{l}4.901^{*} \\
(2.61)\end{array}$ & $\begin{array}{c}4.746^{*} \\
(2.58)\end{array}$ & $\begin{array}{c}4.847^{*} \\
(2.6)\end{array}$ & $\begin{array}{c}2.48 \\
(3.14)\end{array}$ \\
\hline Population & $\begin{array}{c}0.076 * * * \\
(0.02)\end{array}$ & $\begin{array}{c}0.076 * * * \\
(0.02)\end{array}$ & $\begin{array}{c}0.076 * * * \\
(0.02)\end{array}$ & $\begin{array}{c}0.07 * * * \\
(0.01)\end{array}$ & $\begin{array}{c}0.075^{* *} \\
(0.03)\end{array}$ & $\begin{array}{c}0.075 * * \\
(0.03)\end{array}$ & $\begin{array}{c}0.074^{* *} \\
(0.03)\end{array}$ & $\begin{array}{c}0.065^{* *} \\
(0.03)\end{array}$ \\
\hline $\begin{array}{l}\text { R-squared } \\
\text { Number of obs. }\end{array}$ & $\begin{array}{l}0.76 \\
640\end{array}$ & $\begin{array}{l}0.76 \\
640\end{array}$ & $\begin{array}{l}0.76 \\
640\end{array}$ & $\begin{array}{l}0.77 \\
586\end{array}$ & $\begin{array}{l}0.79 \\
144\end{array}$ & $\begin{array}{l}0.79 \\
144\end{array}$ & $\begin{array}{l}0.79 \\
144\end{array}$ & $\begin{array}{l}0.82 \\
131\end{array}$ \\
\hline
\end{tabular}

Notes: The proxy for tax decentralization is subnational tax revenue. The period analyzed is 1986-2010. The estimations include period and country dummies, which are omitted for space considerations. All regressions are estimated with the two-way fixed effects estimator. Robust standard errors are in parentheses. *, ** and *** denote significance at the 10,5 and $1 \%$ levels, respectively. The definitions of the variables can be found in Appendix I. The list of countries included in the sample is shown in Table 2.

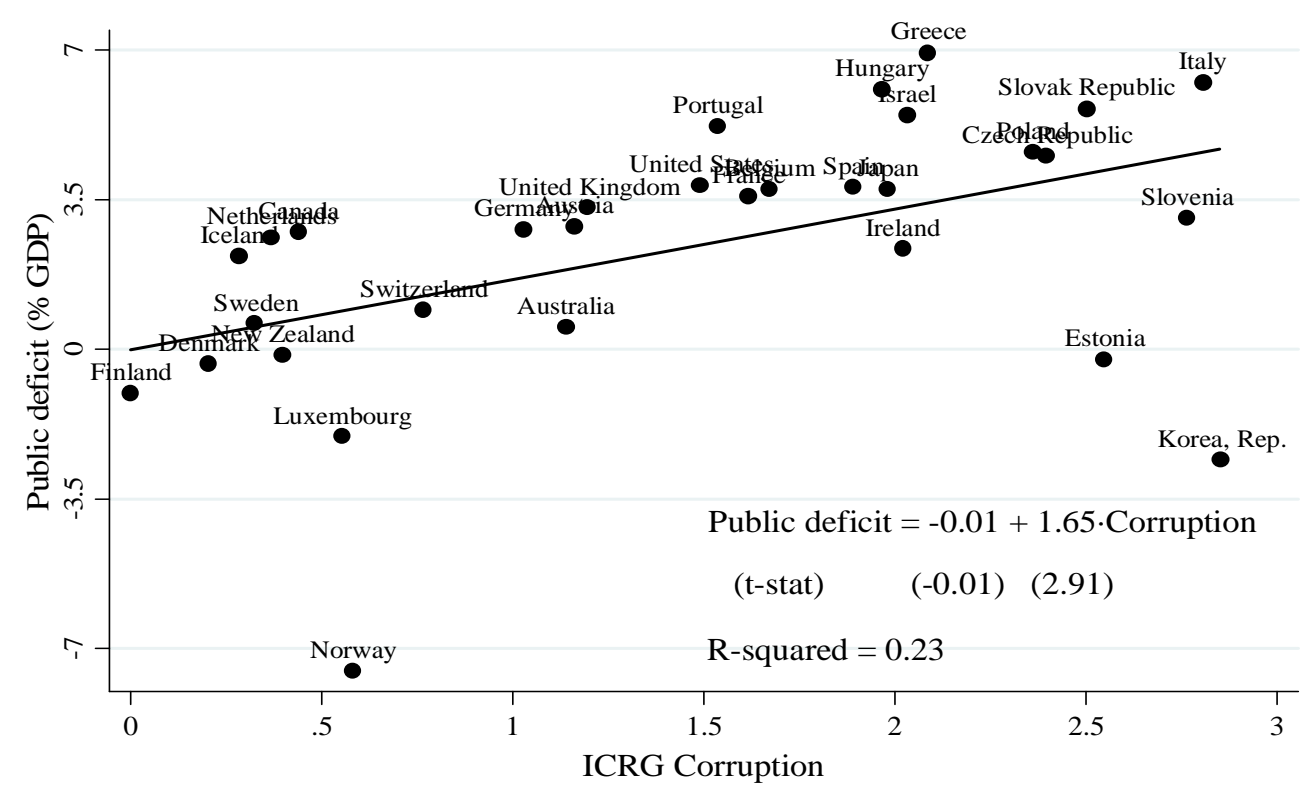

Notes: The variables represent the average of available data over the period 1986-2010.

The definitions and sources of the variables can be found in Appendix I.

Fig. 1. The relationship between public deficit and corruption 


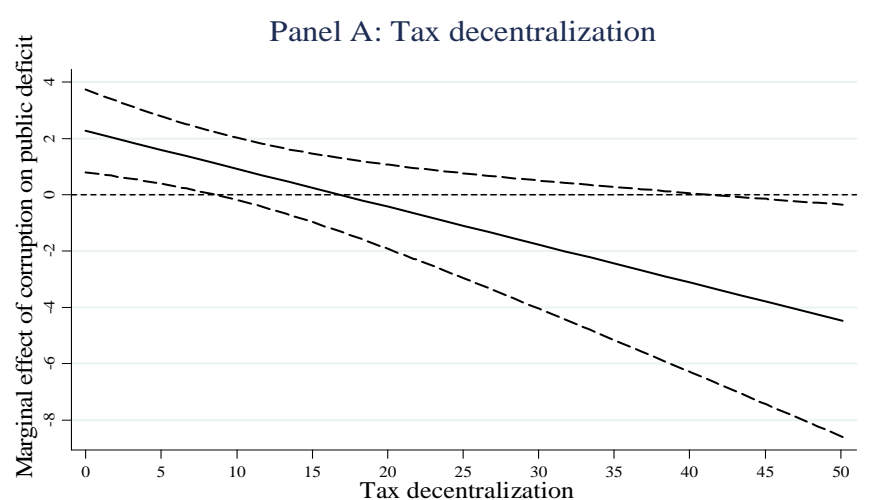

The figure corresponds to regression 3 of Table 3 .
$90 \%$ confidence interval.

Fig. 2. The marginal effect of corruption on public deficit

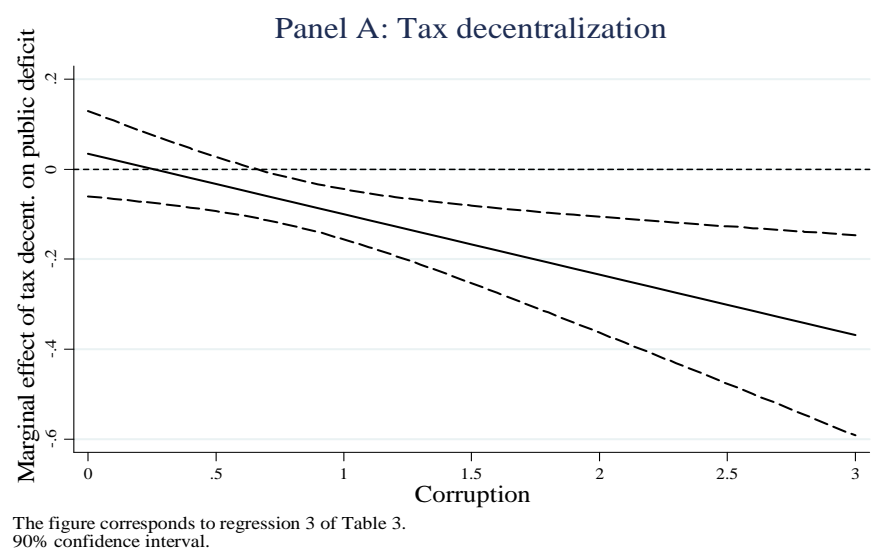

Fig. 3. The marginal effect of fiscal decentralization on public deficit
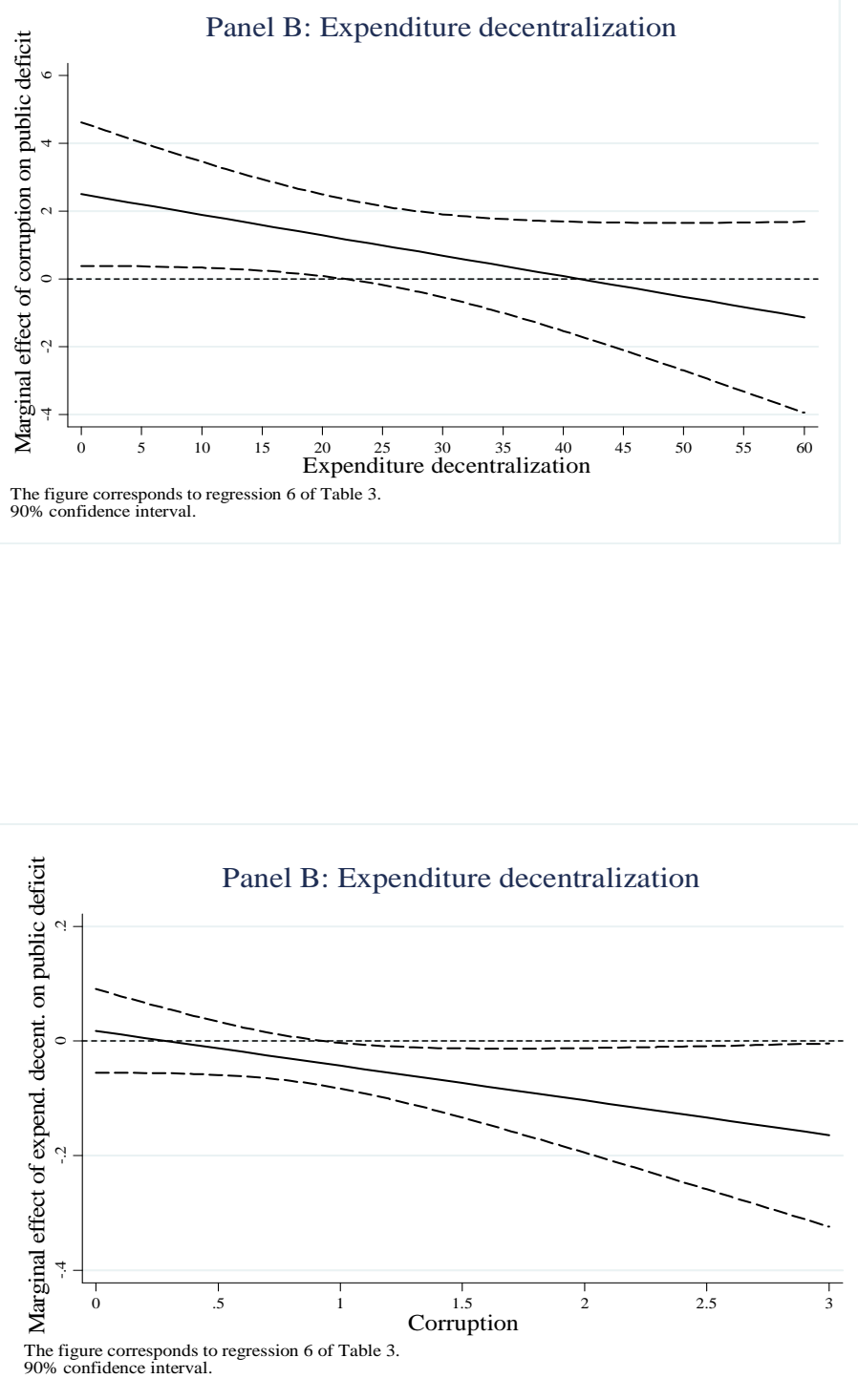


\section{Appendix I. Description of variables.}

\begin{tabular}{|c|c|c|}
\hline VARIABLE & DESCRIPTION & SOURCE \\
\hline $\begin{array}{l}\text { Banking crisis - fiscal } \\
\text { cost }\end{array}$ & $\begin{array}{l}\text { Fiscal costs associated with systemic banking crises. The total fiscal cost is } \\
\text { divided by the years of duration of each crisis. }\end{array}$ & Laeven and Valencia (2012). \\
\hline Banking crisis - dummy & $\begin{array}{l}\text { Dummy variable indicating whether the country experiences a systemic } \\
\text { banking crisis. }\end{array}$ & Laeven and Valencia (2012). \\
\hline Bribe payments & $\begin{array}{l}\text { Experience-based indicator obtained from the question: "In the past } 12 \\
\text { months, have you or anyone living in your household paid a bribe in any } \\
\text { form?" }\end{array}$ & $\begin{array}{l}\text { Global Corruption Barometer, } \\
\text { Transparency International } \\
\text { (several years). }\end{array}$ \\
\hline Control of Corruption & $\begin{array}{l}\text { Perception-based indicator that measures the level of corruption within the } \\
\text { political system. Values range between }-2.5 \text { (highly clean) and } 2.5 \text { (highly } \\
\text { corrupt). }\end{array}$ & $\begin{array}{l}\text { World Bank Governance } \\
\text { Indicators (Kaufmann et al., } \\
\text { 2010), from Teorell et al. (2011). }\end{array}$ \\
\hline $\begin{array}{l}\text { Corruption Perception } \\
\text { Index }\end{array}$ & $\begin{array}{l}\text { Perception-based indicator that measures the level of corruption within the } \\
\text { political system. Values range between } 10 \text { (highly clean) and } 0 \text { (highly } \\
\text { corrupt). }\end{array}$ & $\begin{array}{l}\text { Transparency International, from } \\
\text { Teorell et al. (2011). }\end{array}$ \\
\hline Debt service & Net government interest payments, as a percentage of GDP. & OECD (2012b). \\
\hline Democracy (polity2) & $\begin{array}{l}\text { "Revised Combined Polity Score" measures the degree of democracy vs. } \\
\text { autocracy in the political system. The scale ranges from -10 to 20, where a } \\
\text { higher score means higher democracy. }\end{array}$ & $\begin{array}{l}\text { Polity IV, from Teorell et al. } \\
\text { (2011). }\end{array}$ \\
\hline Federal & Dummy whether the country is a federation. & Treisman (2002). \\
\hline Freedom of press & $\begin{array}{l}\text { Degree of freedom of press considering legislative regulation, political } \\
\text { pressure, economic influences and repressive actions. The scale ranges from } \\
0 \text { to } 100 \text {, where a higher score means lower freedom. }\end{array}$ & $\begin{array}{l}\text { Freedom House, from Teorell et } \\
\text { al. (2011). }\end{array}$ \\
\hline Government fragment. & $\begin{array}{l}\text { "Probability that two randomly chosen deputies from among the government } \\
\text { parties will be of different parties" }\end{array}$ & $\begin{array}{l}\text { Database of Political Institutions, } \\
\text { from Teorell et al. (2011). }\end{array}$ \\
\hline Growth GDP pc & Real per capita GDP growth (annual \%). & $\begin{array}{l}\text { World Development Indicators } \\
\text { (WDI), } 2011 \text { (World Bank). }\end{array}$ \\
\hline i bond & Government bond yield at a 10 -year maturity. & IMF (2012). \\
\hline ICRG Corruption & $\begin{array}{l}\text { Perception-based indicator that assesses the presence of corruption within the } \\
\text { political system. We rescale the variable so that higher score means more } \\
\text { corruption. The scale ranges from } 0 \text { to } 6 \text {. }\end{array}$ & $\begin{array}{l}\text { ICRG (PRS } \\
\text { Group). }\end{array}$ \\
\hline Inflation & Ln (1+ inflation), where inflation is consumer prices (annual \%). & WDI, 2011 (World Bank). \\
\hline Ln GDP pc & Logarithm of real per capita GDP (constant 2000 US\$). & WDI, 2011 (World Bank). \\
\hline Openness & Trade (exports and imports) (\% of GDP). & WDI, 2011 (World Bank). \\
\hline Parliament fragment. & $\begin{array}{l}\text { "Probability that two randomly chosen deputies in the legislature belong to } \\
\text { different parties." }\end{array}$ & $\begin{array}{l}\text { Database of Political Institutions, } \\
\text { from Teorell et al. (2011). }\end{array}$ \\
\hline Population & Total population, in millions. & WDI, 2011 (World Bank). \\
\hline Public deficit & Government deficit (net borrowing) as a percentage of GDP. & OECD (2012b). \\
\hline $\begin{array}{l}\text { Subnational govern. } \\
\text { expend. }\end{array}$ & $\begin{array}{l}\text { Subnational (state/regional and local) government expenditure as percentage } \\
\text { of total general government expenditure. }\end{array}$ & OECD (2012a). \\
\hline Subnational tax revenue & $\begin{array}{l}\text { Subnational (state/regional and local) tax revenue as percentage of total } \\
\text { general government tax revenue. }\end{array}$ & OECD (2012a). \\
\hline TD1 & $\begin{array}{l}\text { Subnational (state/regional and local) tax revenue as percentage of total } \\
\text { general government tax revenue, considering only those taxes in which } \\
\text { subnational units have powers over tax rates and/or tax bases. }\end{array}$ & $\begin{array}{l}\text { Stegarescu (2005) and OECD } \\
\text { (2012a). }\end{array}$ \\
\hline $\begin{array}{l}\text { Total government } \\
\text { revenue }\end{array}$ & Total receipts of general government, as a percentage of GDP. & OECD (2012b). \\
\hline Unemployment rate & $\begin{array}{l}\text { Share of the labor force without employment but available to work and } \\
\text { seeking employment. }\end{array}$ & WDI, 2011 (World Bank). \\
\hline
\end{tabular}

